University of Chicago Law School

Chicago Unbound

Journal Articles

Faculty Scholarship

1961

\title{
The Mersky Case and the Criminal Appeals Act: A Suggestion for Amendment of the Statute
}

Philip B. Kurland

Follow this and additional works at: https://chicagounbound.uchicago.edu/journal_articles

Part of the Law Commons

\section{Recommended Citation}

Philip B. Kurland, "The Mersky Case and the Criminal Appeals Act: A Suggestion for Amendment of the Statute," 28 University of Chicago Law Review 419 (1961).

This Article is brought to you for free and open access by the Faculty Scholarship at Chicago Unbound. It has been accepted for inclusion in Journal Articles by an authorized administrator of Chicago Unbound. For more information, please contact unbound@law.uchicago.edu. 


\section{THE \\ UNIVERSITY OF CHICAGO LAW REVIEW}

VOLUME 28

SPRING 1961

NUMBER 3

\section{THE MERSKY CASE AND THE CRIMINAL APPEALS ACT: A SUGGESTION FOR AMENDMENT OF THE STATUTE}

PHILIP B. KuRLAND $\dagger$

$\mathrm{N}$ OTHER court in the world is called upon to resolve judicial controversies of such importance as those presented to the Supreme Court of the United States. The time available to the nine Justices is patently inadequate for them properly to decide the vital issues before them and to explain satisfactorily the reasons for the results they reach. ${ }^{1}$ It is, therefore, unfortunate that the Court should be called upon to spend its time and energy in the decision of cases that have no importance except to the litigants themselves, ${ }^{2}$ who will ordinarily have had at least one hearing on appeal. It is equally unfortunate that so much of the Justices' time should be occupied with the resolution of questions about the Court's own jurisdiction concerning only the allocation of business within the federal system. ${ }^{3}$ The problem presented by the unimportant cases can be solved in large measure by the Court itself through a wiser utilization of its discretionary power to refuse review. Insofar, however, as such cases come to the Court by way of appeal as of right, the Court would require the assistance of Congress for their elimination from the crowded docket, just as avoidance of the jurisdictional ques-

$\dagger$ Professor of Law, The University of Chicago.

1 See Hart, The Time Chart of the Justices, 73 Harv. L. Rev. 84 (1959); Griswold, Morrison Lecture, 43 MAss. L.Q. 98, 108-09 (1958). But see Douglas, The Supreme Court and Its Case Load, 45 CORNELl L.Q. 401, 411 (1960): "The upshot of these statistics is that we have fewer oral arguments than we once had, fewer opinions to write, and shorter weeks to work. I do not recall any time in my twenty years or more of service on the Court when we had more time for research, deliberation, debate, and meditation." It should be remembered, however, that Mr. Justice Douglas has never felt pressed by the business of the Court. See Cohen, Justice Douglas: A Law Clerk's View, 26 U. CHI. L. Rev. 6, 7-8 (1958).

2 See Hart, supra note 1 , at 96-98.

3 The distribution of jurisdiction among the federal courts does not present the same problems of power that are involved in the distribution of jurisdiction between the state and federal courts. See Frankfurter, Distribution of Judicial Power between United States and State Courts, 13 CORNELL L.Q. 499 (1928). 
tions would require legislative action. For it is to the legislature that the Constitution has assigned the duty of specifying the Court's jurisdiction, except in a few categories of cases. ${ }^{4}$ On the other hand, Congress, with propriety, has usually abstained from relieving the Court of any of its jurisdiction until the Court has indicated its desire so to be relieved. 5 Not since 1925 has there been an adequate examination of the Supreme Court's compulsory jurisdiction. If the time has come, as it has, for reconsideration of the rules of procedure which the Court has promulgated since $1938^{6}$ and for a re-examination of the distribution of judicial power between the states and the nation, 7 certainly the occasion is also at hand for a reassessment of the compulsory jurisdiction of the high tribunal. 8

The patchwork quilt of special jurisdictional statutes under which the Court now operates has long since become obsolete. A few examples suffice to demonstrate the need for reconsideration. Perhaps the most obvious defect is the continued requirement that the Court entertain appeals from district court judgments in suits to enjoin the enforcement of ICC orders. ${ }^{9}$ Indeed, the whole three-judge court problem is one which so heavily burdens not only the Supreme Court but the entire federal judicial system 10 that an evaluation of its compensating benefits, if any, ought to be made. It is time, too, to respond to the questions about the Criminal Appeals Act, Section 3731 of Title 18, asked by Professors Hart and Wechsler: "Is the direct appeal defensible in any of the situations covered by the Act? Is it in all of them?"11

${ }^{4}$ See Hart, The Power of Congress to Limit the Jurisdiction of Federal Courts: An Exercise in Dialectic, 66 HARV. L. REV. 1362 (1953).

5 See generally Frankfurter \& Landis, The Business of the Supreme Court (1928).

6 On April 4, 1960, the Chief Justice of the United States announced the appointment of six committees, pursuant to congressional authorization, to study and to recommend to the Supreme Court amendments to the rules of practice and procedure in the federal courts.

7 In May, 1960, the American Law Institute announced the appointment of Professor Richard Field of Harvard as Reporter for a study of the reallocation of judicial power between the states and the national government. The inspiration for this study came from a speech delivered by the Chief Justice at the previous annual meeting of the Institute in May, 1959. See also Kurland, The Distribution of Judicial Power between National and State Courts, 42 J. AM. Jud. Soc'y 159 (1959).

8 Cf. Griswold, supra note 1, at 109; Griswold, Foreword to The Supreme Court: 1959 Term, 74 HaRv. L. Rev. 81, 85 (1960).

928 U.S.C. $\$ 2325$ (1958); see United States v. Griffin, 303 U.S. 226, 232 (1938). In the 1954 through 1958 Terms, the Court entertained 67 such appeals, of which it disposed of 51 by per curiam opinions. Of the 67 judgments, 46 were affirmed, five were vacated for mootness, three were dismissed, one was vacated, and twelve were reversed. (I am indebted to a study by Mr. Roger Bernhardt, now of the Law Faculty of the University of California (Berkeley), for these statistics.)

10 See Comment, The Three-Judge Federal Court in Constitutional Litigation: A Procedural Anachronism, 27 U. CHI. L. REv. 555 (1960).

11 The Federal Coụrts and the Federal, System 1366 (1953), 
It is to these questions, as underlined by the decision of the Court last Term in United States $v$. Mersky, 12 that this article is directed.

\section{The Mersky CaSe}

The substantive issues in the Mersky case cause one to wonder why the very busy office of the United States Attorney for the Southern District of New York should have bothered to file the information at all, except as its contribution to the battle of the Cold War. If all the facts alleged in the information were true-and for purposes of the litigation it must be assumed that they were-the defendants had purchased ten imported violins manufactured in the Soviet Zone of Germany and so labelled, had relabeled them "Made in Germany" for the purpose of concealing their true origin, and had then sold them to a dealer. For these acts, the defendants-two individuals and a corporation-were charged in ten counts with violation of Section 1304 of Title 19 and, in keeping with the practice of the day, were also charged with conspiracy. 13

The statute that was allegedly violated provided that every imported article must indicate, in English, the country of its origin; it gave the Secretary of the Treasury authority to specify in regulations what words or abbreviations were adequate for such identification; and it provided penalties for willful violation by acts intended to conceal the country of origin. ${ }^{14}$ Pursuant to this statute the Treasury had issued a series of regulations. The first one of relevance to the Mersky case provided that "country of origin, shall be considered to mean the political entity known as a nation." 15 In 1946, a Treasury decision was issued providing that "Germany shall be considered the country of origin of articles manufactured in all parts of the Germany area" including the Russian zone. 16 In 1953, the Treasury issued another decision, which became the subject of controversy in the case.17 It contained several paragraphs relating to "products of Germany, Poland, and Danzig." The first removed the

12361 U.S. 431 (1960).

13 Record, pp. 2-5.

14 The relevant provisions of $\S 1304$ are as follows: "(a) Marking of articles. ... [E]very article of foreign origin ... imported into the United States shall be marked in a conspicuous place as legibly, indelibly, and permanently as the nature of the article (or container) will permit in such manner as to indicate to an ultimate purchaser in the United States the English name of the country of origin of the article. The Secretary of the Treasury may by regulations-

(1) Determine the character of the words and phrases or abbreviations thereof which shall be acceptable as indicating the country of origin...;

(2) Require the addition of any other words or symbols which may be appropriate to prevent deception or mistake as to the origin of the article. ..." 46 Stat. 687 (1930), 19 U.S.C. $\$ 1304$ (a) (1958).

1519 C.F.R. $\$ 11.8$ (1953).

16 T.D. 51527, 81 TreAs. DeC. 179 (1946).

17 T.D. 53210,88 Treas. DeC. 46 (1953). 
products of East Germany, among others, from "most favored nation treatment." The second provided that "for purposes of the value provisions of ... [the Tariff Act] the area of the Soviet Zone of Germany and the Soviet Sector of Berlin shall be treated as another "country." The third provided that "products of the Soviet Zone of Germany, or of the Soviet sector of Berlin shall be marked to indicate Germany (Soviet occupied) as the "country of origin.' "The other paragraphs are irrelevant here. It was on the basis of the language in the third paragraph that the Government claimed that the acts committed by the defendants in relabelling the violins were illegal.

The defendants moved to dismiss the information on the ground that the language of the third paragraph must be considered as prefaced by the introductory phrase of the second ("For the purposes of the value provisions of" the Tariff Act), and that their actions were therefore not banned by the regulation. They also asserted that even if this construction were not a necessary one the regulation was sufficiently ambiguous on this point to preclude criminal prosecution. Judge Noonan, in the district court, agreed with both of defendants' propositions and dismissed the information. ${ }^{18}$ The Government, instead of simply amending the regulation to make clear its construction, filed an appeal with the United States Court of Appeals for the Second Circuit, pursuant to the 1942 amendment to the criminal Appeals Act.19 But the court of appeals held that it lacked jurisdiction because the appeal should have been taken directly to the Supreme Court.20

In an opinion by Judge Lumbard, for a panel including Judges Clark and Medina, the court held "that the dismissal of an information based upon a regulation, or regulations, is comprehended within the scope of the words 'construction of the statute upon which ... information is founded.' "21 Cases falling in that category were appealable directly to the Supreme Court.22 The

18 Record, pp. 9-11.

19 This portion of the statute provides that:

"An appeal may be taken by and on behalf of the United States from district courts to a court of appeals, in all criminal cases, in the following instances:

"From a decision or judgment setting aside, or dismissing any indictment or information, or any count thereof except where a direct appeal to the Supreme Court of the United States is provided by this section." 18 U.S.C. $\S 3731$.

20261 F.2d 40 (2d Cir. 1958).

21 Id. at 43.

22 The statute provides:

"An appeal may be taken by and on behalf of the United States from the district courts directly to the Supreme Court of the United States in all criminal cases in the following instances:

"From a decision or judgment setting aside, or dismissing any indictment or information, or any count thereof, where such decision or judgment is based upon the invalidity or construction of the statute upon which the indictment or information is founded.

"From a decision arresting a judgment of conviction for insufficiency of the indictment or information, where such decision is based upon the invalidity or construction of the statute upon which the indictment or information is founded.

"From the decision or judgment sustaining a motion in bar, when the defendant has not been put in jeopardy." 18 U.S.C. $\$ 3731$ (1958). 
court conceded that the issue had not been specifically resolved by the Supreme Court. It gave no consideration to the actions of two other courts of appeals which had retained jurisdiction under similar circumstances. ${ }^{23}$ It put forth two reasons why construction of the regulation should be treated in the same manner as construction of a statute. First, the "government's need for an authoritative ruling from the highest court may, and usually would, be equally as pressing, and it was to provide such ruling that the Act was passed." 24 Second, "insistence upon a distinction between statute and regulation for purposes of appeal would force the government to elect whether to appeal the construction of the regulations to the court of appeals, or whether to appeal the construction of the statute to the Supreme Court. The alternative to such an election would be the simultaneous prosecution of appeals in both courts. We cannot find that the Congress intended to limit the remedial usefulness of the statute by such an unworkable distinction in the absence of an express purpose to do so."25 Even if it were in error in this conclusion, said the court, the case fell within the third category of cases reviewable directly by the high court: cases in which the dismissal exculpates the defendant without having put him in jeopardy. Such "a decision ... in effect sustained a motion in bar." 26

The court of appeals offered to certify the case to the Supreme Court in accordance with the terms of the Criminal Appeals Act, 27 if the Government so requested. The Government vacillated. It apparently was committed to the position that the case was properly one for the intermediate court and not for the Supreme Court. It secured an extension of time from Circuit Justice Harlan within which to file a petition for certiorari on the jurisdictional question; the conflict among circuits offered comparatively easy access to the Court on the issue. But the Government instead wrote a memorandum inviting the court of appeals to certify the question on its own motion. ${ }^{28}$ The court

23 United States v. Gray, 207 F.2d 237 (9th Cir. 1953); United States v. Goldberg, 225 F.2d 180 (8th Cir. 1955), certificate dismissed sub. nom. Wisniewski v. United States, 353 U.S. 901 (1957).

24261 F.2d at 43. The Court relied upon ROBERTSON \& KIRKHAM, JuRISDICTION of THE Supreme Court of the UntTed States $\$ 176$ ( $2 \mathrm{~d}$ ed. Wolfson \& Kurland 1951), for the proposition quoted in the text. It is regrettable that, aside from this generality, that book had nothing to offer in aid of a solution to the jurisdictional problems presented in the Mersky case.

25261 F.2d at 43-44. This argument overlooks the decision of the Court in United States v. Swift \& Co., 318 U.S. 442 (1943). The court of appeals would be able to entertain both sets of questions.

26261 F.2d at 44.

27 Ibid. The statute provides: "If an appeal shall be taken pursuant to this section to any court of appeals which, in the opinion of such court, should have been taken directly to the Supreme Court of the United States, such court shall certify the case to the Supreme Court of the United States, which shall thereupon have jurisdiction to hear and determine the case to the same extent as if an appeal had been taken directly to that Court." 18 U.S.C. $\$ 3731$ (1958).

${ }^{28}$ Record, pp. 20-23. 
of appeals dispensed with niceties and issued the certificate, reciting that it was doing so at the request of the Government.29 The result was, as the appellees readily pointed out, that "this case presents the phenomenon of an appellant who does not invoke the jurisdiction of this Court." 30 The Supreme Court postponed the question of its jurisdiction to the hearing on the merits ${ }^{31}$ and placed the case on the summary calendar. 32

When the Court announced its judgment in favor of jurisdiction and, on the merits, in favor of the appellees, it was thoroughly divided. Mr. Justice Clark wrote the opinion for the Court sustaining the jurisdiction on the ground that the appeal was justified because the dismissal in the district court was based on the interpretation of a statute within the meaning of the Criminal Appeals Act. Mr. Justice Brennan joined the majority opinion but also wrote a concurring opinion to show that jurisdiction might also rest on the fact that the dismissal was a judgment sustaining a motion in bar without putting the defendant in jeopardy. Mr. Justice Whittaker's "memorandum" indicated disagreement with the majority on the jurisdictional question, acceptance of Mr. Justice Brennan's rationale as to jurisdiction, and agreement with the judgment on the merits. Mr. Justice Frankfurter, joined by Justices Harlan and Stewart, found no basis for Supreme Court jurisdiction in the Criminal Appeals Act and directed his argument primarily to the question whether the case involved interpretation of the statute on which the information was based. Mr. Justice Stewart wrote a dissenting opinion, in which he was joined by Justices Frankfurter and Harlan, concerned largely with the question whether jurisdiction was justified because the trial court's dismissal in effect sustained a plea in bar. Thus, five members of the Court thought jurisdiction could be rested on the base of statutory construction; four rejected that concept. Two members of the Court would sustain the jurisdiction on the motionin-bar thesis; three members of the Court thought that such a rationalization was invalid; four Justices said nothing about this issue. Six Justices held for the defendants on the merits; the other three did not reach the substantive questions.

A. Construction of Statute as Basis for Jurisdiction. The Court appeared to be unanimous in the statement of some of the basic principles relevant to the question whether jurisdiction could be sustained on the ground that the trial court had based its dismissal on a construction of the "statute on which the information ... [was] founded." The purpose of the Criminal Appeals Act was to prevent frustration of congressional legislation in the criminal area by dismissals of indictments or informations which, absent the statute,

29261 F.2d at 44.

30 Appellees' Memorandum in Reply to Memorandum for the United States Regarding Jurisdiction, p. 1.

31359 U.S. 951 (1959).

32 Record, p. 25. 
would not be reviewable. It was also the function of the act to expedite the final solution of questions thus raised. These were the lessons of the legislative history copiously used by both the Court and the dissent. ${ }^{33} \mathrm{~A}$ second agreement was that the Criminal Appeals Act was to be construed narrowly, 34 because appeals by the Government from adverse decisions in criminal cases are basically inimical to our concepts of proper process in criminal jurisprudence. But the acceptance of these propositions by all nine justices did not provide a solution for the specific problem before the Court.

The majority, in effect, sought to evade the issue as framed both by the court of appeals and the minority. After negating the suggestion that a regulation was the same as a statute for the purposes of the Act, 35 the Court justified jurisdiction because "the statute is not complete by itself, since it merely declares the range of its operation and leaves to its progeny the means to be utilized in the effectuation of its command. ... In effect, therefore, the construction of one necessarily involves the construction of the other." 36 The only difficulty with this proposition is that it is not true. First, the statute by itself defines a crime which in many situations would need no explication by way of regulation. Second, there was no question of construction of the statute, unless by construction the Court does not mean the resolution of an ambiguity but only the application of the statute: there was no question here either of the meaning of the statute or of the authority of the Treasury to issue the regulation. The court of appeals recognized this in its opinion when it made reference to the Foster case, 37 which did involve the issue of statutory authority for the regulation. Mr. Justice Stewart pointed out the distinction between the instant case and the Foster case in his dissent. ${ }^{38}$ In the Foster

${ }^{33}$ See 361 U.S. at 434-36, 446-50. But see the legislative history set out in the text accompanying notes $135-138$.

34361 U.S. at $437,454$.

35 "An administrative regulation, of course, is not a 'statute." "Id. at 437.

36 Id. at 437-38.

37 United States v. Foster, 233 U.S. 515 (1914). There "the Supreme Court accepted jurisdiction because the district court had dismissed an indictment-based in part on a regulation of the Postmaster General-on the ground that the regulation was directly in conflict with what it held to be the proper 'construction of the statute' involved. We see no reason to distinguish such dismissals from those in which the court looked to what some officer of the government has done under authority which Congress expressly delegated in order to make possible the enforcement of a statute, and not to what Congress itself has written." 261 F.2d at 43.

38361 U.S. at 453-54: "No contention was made that the statute itself was invalid. The trial court did not question that the statute validly and clearly confers power upon the Secretary of the Treasury to issue a properly worded regulation making the acts of appellees unlawful. This is made apparent by the district judge's statement that "[t]he Secretary could very easily have indicated that East and West Germany should be considered two separate countries for all purposes within the jurisdiction of the Treasury Department. ...' Thus the decision we are asked to review in no way impinges upon or construes the legislation which Congress enacted. Compare United States v. Foster, 233 U.S. 515, 522-23." 
case, Mr. Justice McKenna had sustained jurisdiction for a unanimous Court. He wrote:

The court distinctly ruled that the indictment was in technical or formal details sufficient, and the contention of the parties not only submitted for decision the validity of the regulations of the Postmaster General but also the sufficiency and legality of the returns made by Foster under the provisions of the statutes. The court, it is true, gave especial prominence to the regulations, but the effect of the statutes independently of the regulations was necessarily considered. . . and, besides, a construction of the statutes was necessary to determine the validity of the regulation. 39

The majority ignored the Foster case, which would have been adequate authority for its conclusion had the conclusion rested on a sound foundation of fact, i.e., had the construction of the statute been necessarily involved in the determination of the validity of the regulation. The fact is that all governmental regulations based on statutory authority fall within the rule stated by the Court in Mersky. Thus, the question necessarily to be answered was whether the regulation was to be treated as a statute for purposes of the Criminal Appeals Act. And, indeed, despite its specific rejection of the equation, the Court's opinion indicated recognition of the real problem and acceptance of the court of appeals' rationale:40 "[T] termination of the validity of Acts of Congress, which is pointed to as a desideratum for direct appeal, applies equally to regulations. In practical operation, correction of a regulation by agency revision invariably awaits judicial action." 41 For the future, therefore, it must be accepted that the Court has authorized appeals directly to the Supreme Court from district court dismissals of indictments or informations where the dismissal is based on construction of the regulation which forms the basis for the indictment or information.

Mr. Justice Frankfurter recognized the dearth of judicial authority on which to base an answer to the question; he gave little weight to the Eighth and Ninth Circuit opinions: 42

For the problem in hand, there is no controlling authority in this Court nor are there decisions under other statutes helpful for decision; neither is there a body of practice reflected in lower court decisions over a sufficient period of time, unchallenged here, carrying the weight of professional understanding. The case, therefore, must be decided on the balance of considerations weighed here for the first time.43

In so saying, however, Mr. Justice Frankfurter, like his colleagues, overlooked "a body of practice ... carrying the weight of professional understanding"

39233 U.S. at 523. (Emphasis added.)

40 See text accompanying notes 24-25 supra.

41361 U.S. at 436.

42 Cases cited note 23 supra.

43361 U.S. at 446. 
which should have been considered of great importance. Neither the majority, nor the minority, nor the court of appeals, nor counsel, nor an independent examination of all the cases coming to the Court under the Criminal Appeals Act revealed a single instance in which the Solicitor General had sought to invoke the jurisdiction of the Supreme Court on the ground that a dismissal was based on the construction of a regulation. For the fifty-three years since the enactment of the statute, the office charged with utilization of the Act has apparently construed the statute not to warrant such jurisdiction. Nor has that office been reluctant to seek to extend the Court's jurisdiction under the act. In the Mersky case itself, it was the position of the Government that jurisdiction in the Supreme Court was not warranted. Certainly this long-term conduct by an office which has usually been the best-staffed law office in the federal government ${ }^{44}$ is itself persuasive indication of the want of statutory authority for such review. 45

Although he found some comfort in the legislative language, $46 \mathrm{Mr}$. Justice Frankfurter's argument is essentially stated in three propositions also to be found, explicitly or implicitly, in Mr. Justice Stewart's opinion. First, the difficulties of amending a statute which has been construed by a district court adversely to the Government's contention are vastly greater than the correction of a regulation; 47 an improper judicial construction of a regulation cannot, therefore, have the frustrating effects which the Criminal Appeals Act was intended to avoid.48 Second, in the absence of compulsive legislative history or statutory language, it would be unfortunate to adopt that construction which would add to the burdens of the Court's obligatory jurisdiction.49 When these two factors are combined with recognition that a decision adverse to jurisdiction still leaves the Government free to appeal to a court of appeals in those instances where it chooses not to amend the regulation, the result is compelled. 50

The conflict between the majority and minority on this issue is thus reduced to two questions of judgment which cannot be further refined. Is it as important, or almost as important, to require Supreme Court review in cases presenting problems of construction of regulations as in those offering issues of statutory interpretation? The majority, like the court of appeals, apparently believe that it is. Is it important to reduce the compulsory jurisdiction of the Supreme Court by excluding those cases so that the Court has

44 It is interesting to note that among the occupants of the Office of Solicitor General during this period were John W. Davis, William D. Mitchell, Charles Evans Hughes, Jr., Thomas D. Thacher, Robert H. Jackson, and Charles Fahy.

${ }^{45} C f$. Frankfurter, J., dissenting, in United States v. American Union Transp. Inc., 327 U.S. 437, 459 (1946).

46361 U.S. at 450.

47 Ibid.

$49 \mathrm{Id}$. at $451-52$.

48 Id. at 454-55.

so Id. at 452,455 n.4. 
more time for adequate consideration of more important matters? Quite clearly those whose view coincides with that expressed by $\mathrm{Mr}$. Justice Douglas 51 find this a weightless factor in decision. Those of Mr. Justice Frankfurter's persuasion 52 weigh it heavily in reaching a conclusion as to the meaning of the Criminal Appeals Act.53 Apparently most members of the Court fall into the category of judges operating under the maxim "boni judicis est ampliare jurisdictionem."

B. Motion in Bar as the Basis for Jurisdiction. The second jurisdictional question in Mersky is the more interesting one and, perhaps, the more important one. Since there was no decisjon by the Court on the subject, it remains an open question. It appears first in the reports in $\mathrm{Mr}$. Justice Brennan's concurring opinion, but it is obviously second in time, for it is discussed by way of response to the dissenters' position. Rather testily, Mr. Justice Brennan asserted: "Except that arguments are made here in dissent which would unsettle what has been settled by our precedents and reintroduce archaisms into federal criminal procedure, I would have refrained from expressing my views." 54 The resort to the second jurisdictional question by the minority was, of course, not a whim. Having rejected the statutory-construction ground for jurisdiction, they were required to turn to an examination of the alternative, an examination unnecessary for the majority and, indeed, left untouched by all of them except Mr. Justice Brennan. Only Mr. Justice Whittaker joined the concurring opinion; he had to reach the issue because he, too, rejected the ground of jurisdiction adopted by the Court. Mr. Justice Brennan's notion that the minority was unsettling settled law is rather reminiscent of Mr. Justice Harlan's language in Parke, Davis 55 regarding the certainty which the Colgate doctrine created, and is of no greater validity. 56 Before that factor is considered there must be a more exact description of the conflict between the Brennan-Whittaker position and that of Justices Frankfurter, Harlan, and Stewart.

There was agreement among all the Justices concerned with this jurisdictional issue that the question whether defendants' motion in Mersky was a "motion in bar" did not turn on the label placed on the motion by the de-

51 Douglas, supra note 1.

52 "Apart from other vital factors, increase in the range and mass of materials drawn upon in opinions during recent decades, and the investigation and appraisal thereby involved, entail a considerable increase in the burden of the Court's business compared with earlier periods." 361 U.S. at 451 n.3.

53 ". . . I not only feel free, but deem it incumbent to oppose what is certainly a needless if not an irrational increase in the class of cases which can be brought directly to this Court from the District Courts. ..." Ibid.

54 Id. at 441.

$5 s$ United States v. Parke, Davis \& Co., 362 U.S. 29, 57 (1960).

56 See Levi, The Parke, Davis-Colgate Doctrine: The Ban on Resale Price Maintenance, 1960 SuP. CT. Rev. 258. 
fendants. 57 This much of the law really was settled.58 But this emphasis on the underlying realities rather than labels was soon dissipated, and the conflict between the two factions turned thereafter largely on what the Court had said rather than on what the Court had done. The dissent placed primary reliance on the language of Mr. Justice Holmes in Storrs, that the statutory term "plea in bar" was to be given the technical meaning its origins demanded;59 it moved from there by rather more doubtful steps to equate the technical meaning with a plea which in substance was one of confession and avoidance, i.e., one presenting an affirmative defense. $60 \mathrm{Mr}$. Justice Brennan rested his case largely on the language of Hark 61 and Murdock62 to the effect that any motion which, if granted, will bar further prosecution, constitutes a "motion in bar." He found no conflict with Storrs. $63 \mathrm{Mr}$. Justice Frankfurter did see a conflict between Hark and Storrs, and, not untypically, chose to abide by the Holmes judgment.64 Mr. Justice Stewart made the same choice, but he was not equally clear that conflict between the two existed.65

The language of these earlier opinions to one side, Mr. Justice Brennan's main complaint about the dissenters' view was that it was unduly technical. The construction of the Criminal Appeals Act offered by the minority, however, was no more technical than the construction given by the majority to the regulation on the substantive issue. The technicality of the Court's construction of the issues on the merits was justified because of the fact that adequate notice is an essential element of proper process when the defendant is in a position to lose his liberty for failure to act in accordance with the terms of the regulation. On the other hand, the technicality, if that is what it was, when used against the Government's right of appeal is equally justified; "appeals by the Government in criminal cases are something unusual, exceptional, not favored."66 Moreover, as Mr. Chief Justice Warren has also said:

57361 U.S. at $441-42,456$.

58 See United States v. Barber, 219 U.S. 72, 78 (1911); United States v. Oppenheimer, 242 U.S. 85, 86 (1916); United States v. Thompson, 251 U.S. 407, 412 (1920); United States v. Noveck, 271 U.S. 201 (1926) ("motion to quash"); United States v. McElvain, 272 U.S. 633 (1926) (pleas of various appellations); United States v. Storrs, 272 U.S. 652, 654 (1926); United States v. Goldman, 277 U.S. 229, 236-37 (1928); United States v. Murdock 284 U.S. 141, 147 (1931); United States v. Durkee Famous Foods, Inc., 306 U.S. 68 (1939) ("motion to quash"); United States v. Hark, 320 U.S. 531, 536 (1944).

59 United States v. Storrs, 272 U.S. 652, 654 (1926): "The statute uses technical words, 'a special plea in bar,' and we see no reason for not taking them in their technical sense."

${ }^{60}$ See text accompanying note 72 infra.

61 United States v. Hark, 320 U.S. 531, 536 (1944).

62 United States v. Murdock, 284 U.S. 141, 147 (1931).

63361 U.S. at $441-42$.

$64 \mathrm{Id}$. at $452-53$.

$65 \mathrm{Id}$. at 457 n.7.

66 Warren, C.J., in United States v. Carroll, 354 U.S. 394, 400 (1957). 
"[F]orm is substance with respect to ascertaining the existence of appellate jurisdiction." 67

Again, the language of the prior cases to one side, the most telling argument for the dissent is that the grosser construction offered by Mr. Justice Brennan eats up the other provisions of the statute. "Every motion based upon the invalidity of a statute would, under the rough and ready definition of the Court of Appeals [and of Mr. Justice Brennan], also be a 'motion in bar,' because a dismissal based upon such a motion would with equal effectiveness 'end the cause and exculpate the defendants." "68 Mr. Justice Brennan's answer was hardly adequate. He pointed out that a dismissal for failure "to allege facts sufficient to indicate a constitutional application of the statute" might provide a basis for appeal under the Criminal Appeals Act "as from a judgment based on the validity of the statute. Yet such a judgment would not necessarily exculpate the defendant, and this would not constitute the sustaining of a plea in bar, for a new indictment for the same criminal offense might be found by alleging sufficient additional facts to obviate the constitutional defect." $69 \mathrm{He}$ might more strongly have supported his position by accepting the fact that under his thesis all the cases of the first two categories fall into the third category, and then proceeding to argue that the third category was meant to sweep within the statute all cases which tended to exculpate the defendant without the necessity for trial; that the first two categories were only specific examples of the kind of case meant to be covered by the third; or that it was intended to include all pleas in bar, special and general, as distinguished only from pleas in abatement. ${ }^{70}$

The validity of such arguments in vacuo can only be tested in the light, such as it may be, of the decisions of the Court under this rubric of appeals from judgments sustaining "pleas in bar." Preliminarily, however, two points must be taken as established. The first is that the 1948 change in the statutory language made no change in substance.

Until 1948 the Criminal Appeals Act provided for direct appeal to this Court from a "decision or judgment sustaining a special plea in bar, when the defendant has not been put in jeopardy." In 1948 the phrase "motion in bar" was substituted for "special plea in bar." 62 Stat. 845. The sole purpose of the change was to bring the terminology of the Criminal Appeals Act into conformity with Rule 12 of the Federal Rules of Criminal Procedure which abolished special pleas, demurrers and motions to quash as such... The statutory revision was not intended to, and did not, expand the Government's right of appeal. See H. R. Rep. No. 304, 80th Cong., 1st Sess. A-177. That right is still limited to a judgment sustaining a motion of a kind historically considered a "special plea in bar."71

67 Id. at 406.

68361 U.S. at 458 . The same might equally be said about the construction as well as the invalidity of the statute on which the indictment was based.

69361 U.S. at 444 n.2.

70 See text at note 170 infra.

71361 U.S. at 456. 
The second is that historically the term "special pleas in bar" did have a restricted technical meaning. What the meaning was, however, was put rather broadly by Mr. Justice Stewart, perhaps in an attempt to encompass as many as possible of the prior adjudications on the subject.

At common law, a plea in bar had to either "deny, or confess and avoid the facts stated in the declaration." 1 Chitty, Pleading (16th Am. ed. 1883), *551; Stephen, Principles of Pleading (3d Am. ed. 1895), 89. Consequently, there were two types of pleas in bar-pleas by way of traverse and pleas by way of confession and avoidance. Ibid. Shipman, Common-Law Pleading (Ballantine ed. 1923), 30. When a plea in bar was a plea other than the general issue, it was a "special plea in bar." Shipman, supra, at 337; Stephen, supra, at 179. In civil cases pleas of this category included the specific traverse (equivalent to a special denial), the special traverse (a denial preceded by introductory affirmative matter), and the plea of confession and avoidance. In criminal cases special pleas in bar were primarily utilized by way of confession and avoidance, e.g., autrefois acquit, autrefois convict, and pardon. 2 Bishop, New Criminal Procedure (2d ed. 1913), $\$ \$ 742,805-818$; Heard, Criminal Pleading (1879), 279-296; 1 Starkie, Criminal Pleading (2d ed. 1822), 316-338. The plea in confession and avoidance did not contest the facts alleged in the declaration, but relied on new matter which would deprive those facts of their ordinary legal effect. Stephen, supra, 89, 205-206; Shipman, supra, 348; 1 Chitty, supra, *551-*552. It set up affirmative defenses which would bar the prosecution.72

It must have been this bit of antiquarian learning that stirred Mr. Justice Brennan's ire: "To turn the thrust of these precedents around and focus on the common-law pigeonhole of the defendant's plea would be an anomaly indeed, as is recognized, particularly 15 years after the Federal Rules of Criminal Procedure swept away the old pleas."73 What Mr. Justice Brennan did not point out is that the authorities tendered by Mr. Justice Stewart suggest not the broader doctrine of affirmative defenses but rather that the examples cited, i.e., autrefois convict, autrefois acquit, and pardon, in fact exhausted the category of special pleas in bar in criminal cases. Mr. Justice Brennan was not, however, seeking to narrow the scope of the review but rather to expand it.

It is appropriate then to turn to the cases which have come to the Court under the rubric of special plea in bar to see, not only what the Court has said about them, but also what the Court has done about them.

1. Autrefois convict and autrefois acquit. Under any construction given the Criminal Appeals Act, the technical special pleas in bar, autrefois acquit, autrefois convict, and pardon, must be included among those which, if sustained, will provide a base for appeal to the Supreme Court. There still remains, however, the question what is included within these special pleas in bar.

The first case coming to the Court on this basis was United States $v$. Mason. 74 The defendants had been indicted under a statute which made it

72 Id. at 457.

73 Id. at 442.

74213 U.S. 115 (1909). 
criminal to conspire to interfere with the exercise of any right guaranteed by the national Constitution. It provided further that if any other felony or misdemeanor was committed in the course of violation of the conspiracy section, such misdemeanor or felony should be punished to the same extent as it would be punished under the laws of the state in which the acts were committed. The indictment charged that, pursuant to a conspiracy to interfere with Joseph A. Walker's right to vote, the defendants murdered him. The defendants filed a special plea in bar to the indictment, insofar as it sought punishment because of the killing, on the ground that they had been previously tried and acquitted of the murder in the state court. The law established by the Supreme Court has long been, and continues to be, that prior acquittal or conviction in a state court does not constitute double jeopardy within the meaning of the Fifth Amendment. 75 The Supreme Court accepted jurisdiction and sustained the plea. But, on the merits, it did not sustain a claim of constitutional right.76 Writing for a unanimous Court, the first Mr. Justice Harlan construed the statute to preclude the prosecution: "The language of that section is entirely satisfied and the ends of justice met if the statute is construed as not embracing, nor intended to embrace, any felony or misdemeanor aga ist the State of which, prior to the trial in the Federal court for the Federal offense charged, the defendants has been lawfully acquitted of the alleged state offense by a state court having full jurisdiction in the premises."77

The decision may be read, for purposes of ascertaining the meaning of the Criminal Appeals Act, to mean that the plea of autrefois convict or autrefois acquit properly goes beyond the constitutional meaning of double jeopardy, that it includes statutory bans on retrial as well. Or it may be read to mean that when the trial court sustains a plea of autrefois convict, or autrefois acquit, on appeal the Court is entitled to examine the question whether the statute authorizes the indictment to be brought, i.e., to construe the statute even though the trial court had not based its action on the construction of the statute. On this thesis, the door to the Supreme Court having been opened, it is free to consider any question encompassed by any of the provisions of the act. There is later evidence to support both readings.

Mr. Justice Holmes' opinion in United States v. Oppenheimer 78 made it clear that at least the first of these alternatives was valid. There the defendants had successfully defended against an indictment on the ground of bar by

75 See Abbate v. United States, 359 U.S. 187 (1959); Grant, The Lanza Rule of Successive Prosecutions, 32 Colum. L. Rev. 1309 (1932); Grant, Successive Prosecutions by State and Nation: Common Law and British Empire Comparison, 4 U.C.L.A. L. REv. 1 (1959; Comment, Successive Prosecutions by State and Federal Governments for Offenses Arising out of Same Act, 44 MnNN. L. Rev. 534 (1960); see also Mayers \& Yarborough, Bis Vexari: New Trials and Successive Prosecutions, 74 HARv. L. REv. 1, 3-8 (1960).

76213 U.S. at 122-23.

77 Id. at 124.

78242 U.S. 85 (1916). 
limitations. After that judgment was entered, the Supreme Court decided a case revealing that the wrong statute of limitations had been applied. The Government secured another indictment on the same grounds. The trial court dismissed the indictment by granting a "motion to quash" which asserted the first decision by way of bar. On the jurisdictional question, the United States argued that the trial judge's action, labelled a disposition of a motion to quash was one sustaining a special plea in bar: "whether considered as setting up former jeopardy, res adjudicata, or limitation, [the motion] constituted a special plea in bar and could have constituted nothing else."79 This was not a concession that res judicata was a proper plea in bar. For on the merits, at which the Court quickly arrived, the Government's position was, in essence, that "the plea of res adjudicata is unknown to the criminal law. The attempt to interpose it here is novel, but not allowable." 80 Mr. Justice Holmes dispatched that argument very quickly and in the course of so doing added or approved the broader category of pleas in bar, not only technical pleas of autrefois convict or autrefois acquit but also pleas of similar nature. Certainly they were not to be limited to constitutional bans on double jeopardy:

Of course the quashing of a bad indictment is no bar to a prosecution upon a good one, but a judgment for the defendant upon the ground that the prosecution is barred goes to his liability as matter of substantive law and one judgment that he is free as matter of substantive law is as good as another. A plea of the statute of limitations is a plea to the merits, United States v. Barber, 219 U.S. 72, 78, and however the issue was raised in the former case, after judgment upon it, it could not be reopened in a later prosecution. We may adopt in its application to this case the statement of a judge of great experience in the criminal law. "Where a criminal charge has been adjudicated upon by a court having jurisdiction to hear and determine it, that adjudication, whether it takes the form of an acquittal or conviction, is final as to the matter so adjudicated upon, and may be pleaded in bar to any subsequent prosecution for the same offence. ... In this respect the criminal law is in unison with that which prevails in civil proceedings." Hawkins, J., in The Queen v. Miles, 24 Q.B.D. 423, 431. ...

The safeguard provided by the Constitution against the gravest abuses has tended to give the impression that when it did not apply in terms, there was no other principle that could. But the Fifth Amendment was not intended to do away with what in the civil law is a fundamental principle of justice (Jeter v. Hewitt, 22 How. 352, 364 ), in order, when a man once has been acquitted on the merits, to enable the Government to prosecute him a second time. ${ }^{81}$

The breadth of the Holmes opinion was narrowed in United States $v$. Lanza, 82 but the limitation came only with regard to the merits and not with reference to the jurisdictional question. In that case the defendant had assert-

79 Brief for the United States, p. 16.

80 Brief for the United States in Opposition to Motion to Dismiss, p. 9.

81242 U.S. at 87-88.

82260 U.S. 377 (1922). See Grant, supra note 75. 
ed as a plea in bar an earlier conviction in the state court for the same act for which he was indicted in the federal court. The trial court sustained the defendant's "special plea in bar." The Supreme Court showed no doubts about its jurisdiction. It held, however, that a special plea in bar by way of prior conviction in a state court should not have been sustained. "If Congress sees fit to bar prosecution by the federal courts for any act when punishment for violation of state prohibiton has been imposed, it can, of course, do so by proper legislative provision; but it has not done so." 83 No hint is given whether, where the plea rests on the federal statute under which the indictment was brought, the proper course is to come up on the basis of the statutory construction rather than to base the appeal on the plea in bar.

In United States v. Adams, 84 the Court, through Mr. Justice Holmes, disposed of two appeals. Both involved pleas of former acquittal. The case on which the pleas were based involved an indictment for a false entry in a banking transaction in violation of national law. The indictment in the first of the two cases under review charged a second false entry of the same transaction. The second of the cases involved a charge of false entry based on a different transaction. The Court found no difficulty in asserting its jurisdiction over the appeals from the trial court's ruling in favor of the defendant on pleas of former acquittal. It sustained the trial court on the question of a second entry on the same transaction. It reversed the judgment, with some doubts, where the entry charged involved a different transaction than that of the original case: "[A]lthough not technically a former acquittal, the judgment was conclusive upon all that it decided." 85 The first judgment could not decide, however, the question of the defendant's state of mind at the time of the second entry, and the issue of intent might have been the basis for the first acquittal. For the purposes of the Criminal Appeals Act, the interesting implication is that a plea which asserts collateral estoppel as a bar, no less than one setting forth acquittal on the same charge as to the same facts, falls into the category of the special plea in bar.

The last of the cases under this rubric was United States $v$. Williams. ${ }^{86}$ There the defendant had been convicted of substantive offenses at an earlier trial. He was then indicted on the ground that he had committed perjury at the first trial. A motion in bar asserting prior trial and conviction was sustained. On review, the Supreme Court distinguished former jeopardy from res judicata. As to the first, Mr. Justice Reed said: "The conviction of Williams, at a former trial . . . is not former or double jeopardy. Obviously perjury at a former trial is not the same offense as the substantive offense .... 'It is only an identity of offenses which is fatal.' Pinkerton $v$. United States, 328 U.S. 640, 644, and cases cited. . . . Appellees' brief treats Williams' con-

83260 U.S. at 385.

84281 U.S. 202 (1930).
85 Id. at 205.

86341 U.S. 58 (1951). 
viction as grounds for estoppel or res judicata."'87 But the Court rejected the contention on the estoppel point as well. Justices Black and Frankfurter dissented. Thus, while the Court clearly drew the line between former jeopardy and res judicata, it appeared to have accepted the assertion of either as the assertion of a special plea in bar.

In sum, the cases brought to the Court as pleas in bar under the notion of autrefois convict or autrefois acquit-there were no pardon cases-were not rigidly restricted to defenses of double jeopardy but included defenses of estoppel by judgment, including collateral estoppel. The common-law concept of special pleas in bar has obviously been expanded beyond its strict definition, but not, in these cases at least, beyond the notion of a plea in confession and avoidance. Each of the cases satisfies both the narrow construction of the dissent and the more latitudinarian views of Justices Brennan and Whittaker.

2. Statutes of limitations. The largest single category of cases coming to the Supreme Court under the "special plea in bar" category involves those dealing with statutes of limitations. The first case to come to the Court presenting such a problem was United States $v$. Biggs. ${ }^{88}$ The Court seemed to assume that it had power to entertain an appeal from a dismissal granting a plea asserting the statute of limitations, 89 but found no need to consider the issue after disposing of the case on a question of statutory construction. 90 Shortly thereafter the Kissel case came to the Court; the only basis for jurisdiction was an appeal from a dismissal based on the plea of limitations. 91 The Court, through an opinion by Mr. Justice Holmes, accepted the labelling of the plea of limitations as a "plea in bar" for the purposes of jurisdiction over the appeal. At the same time, however, the ruling of Kissel was that limitations were not properly raised by a plea in bar: such an issue must be asserted by way of general issue rather than special plea. The same result was reached in United States $v$. Barber,92 where Mr. Chief Justice White delivered the opinion:

We find it necessary, however, to consider but one [contention], wherein it is claimed that "a special plea in bar is not permissible in a criminal case, but the defense of the statute of limitations must be made under the general issue." This contention, as applied to the character of the case now under consideration must be sustained, upon the authority of . . . Kissel .... In that case it was held that where an indictment charges a continuing conspiracy, which is expressly alleged to have continued to the date of the filing of the indictment, such allegation must be denied under the general issue and not by a special plea [in bar] . . .93

$87 \mathrm{Id}$. at 62.

88211 U.S. 507 (1909).

${ }^{89}$ There is some indication that the congressional understanding was the same. See note 170 infra.

90211 U.S. at 522.

92219 U.S. 72 (1911).

91 United States v. Kissel, 218 U.S. 601 (1910).

$93 \mathrm{Id}$. at 78 . 
When the problem next came to the Court, in United States v. Rabinowich, 94 it was ignored both by counsel and by the Justices. The Court simply accepted jurisdiction without question; and since the Rabinowich decision, the defense of limitations has been considered a "plea in bar" and a dismissal based on such a defense has been directly reviewable in the Supreme Court.95

The propriety of this position was fully debated in the briefs in United States v. Goldman,96 and the issues thus presented shed some light on the Mersky problem. In Goldman the defendants had moved to dismiss on the ground "that it appears on the face of the information that this proceeding . . . was instituted more than one year after the date of the alleged act or acts complained of . ..."97 The Government demurred to the motion; the trial court granted the motion and dismissed the information. In asserting jurisdiction in the Supreme Court, the Government argued:

In some older cases, it is true, language may be found to indicate that the common function of a special plea in bar was to set up new matters dehors the record. This does not mean, however, that every special plea in bar, to fulfill its definition, must thus set up new matter. The language in the older cases should, we submit, be considered in the light of the earlier law. At common law, only four kinds of special pleas in bar (namely, autrefois convict, autrefois acquit, autrefois attaint, and pardon), were recognized in criminal cases; and each of these four did, in fact, serve to set up new matter. At common law there were no statutes of limitations in criminal cases; and pleas in bar based upon such statutes were accordingly unknown. In modern practice, on the contrary, as is shown by many cases in this Court, the defense of the statute of limitations may regularly and properly be raised by a special plea in bar; and such a plea need not (and frequently does not) set up new matter. ... [The Government here referred to two Criminal Appeals Act cases: Rabinowich and Noveck. $]^{98}$ The failure to set up new matter has never been held to make the plea defective or to change its essential nature. 99

In their brief, however, the defendants challenged the analysis and argument offered by the Government. Like the dissent in Mersky, their argument was bottomed on the assertion by Mr. Justice Holmes in Storrs that the term "special plea in bar" must be given its technical meaning.

The words "special plea in bar" have long since acquired a well-settled meaning in the law. Those pleas appeared first in the civil law and subsequently in the criminal law. The essential and fundamental characteristic of a special plea (whether it be in

94238 U.S. 78 (1915).

95 United States v. Noveck, 271 U.S. 201 (1926); United States v. McElvain, 272 U.S. 633 (1926); United States v. Scharton, 285 U.S. 518 (1932); United States v. Durkee Famous Foods Inc., 306 U.S. 68 (1939) (3 cases); United States v. Smith, 342 U.S. 225 (1952) (2 cases); United States v. Berman, 345 U.S. 979 (1953); United States v. Grainger, 346 U.S. 235 (1953) (3 cases).

96277 U.S. 229 (1928).

97 Record, p. 45.

98 See notes 94 and 95 supra.

99 Brief for the United States, pp. 22-23. 
bar or in abatement) is that it denies the right of the Government to succeed by reason of facts extrinsic to the indictment. As long ago as 1824, Starkie in 1 Criminal Pleadings 349, said:

"By the plea in bar, the defendant shows, by matter extrinsic to the record, that the indictment is not maintainable."

Bishop adopts this definition in the same language (2 Bishop's New Criminal Procedure, 2d Ed. 1913, p. 583).

Mr. Justice Gray said for this Court in Farley v. Kittson, 120 U.S. 303, at page 315:

"The distinction between a demurrer and a plea dates as far back as the time of Lord Bacon, by the 58th of whose Ordinances for the Administration of Justice in Chancery, 'a demurrer is properly upon matter defective contained in the bill itself, and no foreign matter; but a plea is of foreign matter to discharge or stay the suit, as that the cause hath been formerly dismissed, or that the plaintiff is outlawed or excommunicated, or there is another bill depending for the same cause, or the like.' Orders in Chancery (Beames' ed.) 26. Lord Redesdale, in his Treatise on Pleadings, says: 'A plea must aver facts to which the plaintiff may reply, and not, in the nature of a demurrer, rest on facts in the bill.' Mitford P1. 297. And Mr. Jeremy, in a note to this passage, commenting on the ordinance or Lord Bacon, observes, "The prominent distinction between a plea and a demurrer, here noticed, is strictly true, even of that description of plea which is termed negative, for it is the affirmative of the proposition which is stated in the bill'; in other words, a plea which avers that a certain fact is not as the bill affirms it to be, sets up matter not contained in the bill."

The distinction between demurrers or motions to dismiss, on the one hand, and pleas, on the other, is clear. The former set forth nothing new, but merely raise the issue of law that if everything alleged in the indictment be taken to be true, the Government cannot succeed. The latter, in contrast thereto, set forth one or more extrinsic facts necessary to the defense that the defendant asserts. 100

The similarity between the contentions here and those in Mersky is striking. The defendants in error proceeded to attempt to distinguish the cases in which the Court had accepted jurisdiction over dismissals based on the defense of limitations.

It is true that the defense of the statute of limitations has usually been raised in pleadings that are properly called "special pleas in bar," rather than by demurrers or by motions to dismiss. That, however, is merely due to an accident rather than to anything inherent in their nature. The statute of limitations customarily pleaded is found in R.S. 1044; and that is restricted by R.S. 1045 so as not to apply to any person fleeing from justice. ... Therefore, whenever a defendant has desired the benefit of that statute of limitations, his pleading, of necessity, had to be a special plea in bar setting up the additional fact not appearing in the indictment, viz., that the defendant was not a fugitive from justice.101

100 Brief for the Defendants in Error, pp. 16-17.

101 Id. at 18-19. 
The brief for the defendant continued with language still reminiscent of the dissenters' argument in Mersky:

The Government admits that the language of the earlier cases is in accordance with the rule as we have stated it, that the function of a special plea in bar is to set up new matter. The Government intimates that the rule has perhaps been changed, and states (without the citation of authority) that a plea in bar does not have to set up new matter and that the failure to do so is not essential to its nature. Obviously, this cannot be so, for if it were true, the careful distinction that Congress has drawn between the first and second subdivisions, on the one hand, and the third subdivision, on the other, would be meaningless. ${ }^{102}$

Faced with these conflicting arguments, the Court did what the Court has so often done. It disposed of the case summarily in an opinion which did not meet the issues: "Here the motion to dismiss raised the bar of the statute of limitations upon the facts appearing on the face of the information, and was equivalent to a special plea in bar setting up such facts. And the effect of sustaining the motion was the same as if such a special plea in bar had been interposed and sustained."103 The Goldman case was an expansive reading of the Criminal Appeals Act in several respects. It specifically brought cases instituted by information within the statute's ambit, although the statutory language at the time referred only to indictments; it also held that criminal contempt proceedings were criminal cases for purposes of the statute. Most important, however, it apparently enlarged the "plea in bar" category to include by analogy defenses which did not take the form of pleas in confession and avoidance. It is probably the strongest authority, especially in light of counsel's arguments, on which the Brennan position can rest.

3. Other "special pleas in bar" sustaining jurisdiction. The first case arising under the "special plea in bar" section which did not involve an issue of multiple jeopardy or statute of limitations was United States v. Celestine.104 In that case the defendant, an Indian, had moved for dismissal by a plea asserting that the federal court lacked jurisdiction to try him for murder because the land on which the killing had taken place had been allotted to him by law, and he had received a grant of full rights of citizenship, removing him from the jurisdiction exercised by federal courts over "protected" Indians. On its face, the case seemed to present a question of statutory construction bringing it within the Criminal Appeals Act on that ground. But jurisdiction was accepted under the "plea in bar" provision. Mr. Justice Brewer was particularly unenlightening as to the reason for the existence of jurisdiction on this basis.

The fourth paragraph of ... [the Criminal Appeals Act] authorizes a review of a "decision or judgment sustaining a special plea in bar, when the defendant has

102 Id. at 19-20. There is some support in the legislative history for this reading of pleas in bar. See note 155 infra.

103277 U.S. at $236-37$.

104215 U.S. 278 (1909). 
not been put in jeopardy." The defendant in this case had not been put upon trial, therefore he had not been in jeopardy. The decision of the Circuit Court sustained the special plea in bar. This fourth paragraph differs from the two preceding, in that the review authorized by them is limited to cases in which "the decision or judgment is based upon the invalidity or construction of the statute upon which the indictment is founded," while no such limitation appears in this paragraph. The full significance of this difference need not now be determined, but clearly the fourth paragraph gives to this court a right to review the precise question decided by a trial court in sustaining a special plea in bar, although that decision may involve the application rather than the invalidity or construction, strictly speaking, of the statute upon which the indictment was founded. ${ }^{105}$

It is possible to understand the Court's language to mean that the earlier sections of the Criminal Appeals Act included only holdings of invalidity on the face of the statute. The Court has frequently been concerned with the distinction between the unconstitutionality of a statute and its unconstitutional application. ${ }^{106}$ But no such jurisdictional line between the construction of a statute and its application to particular facts has been suggested. And indeed, it would appear that construction of a statute was exactly what the Court pretended to do in the Celestine case:

Notwithstanding the gift of citizenship, both the defendant and the murdered woman remained Indians by race, and the crime was committed by one Indian upon the person of another, and within the limits of a reservation. Bearing in mind the rule that the legislation of Congress is to be construed in the interest of the Indian, it may fairly be held that the statute does not contemplate a surrender of jurisdiction over an offense committed by one Indian upon the person of another Indian within the limits of a reservation; at any rate, it cannot be said to be clear that Congress intended by the mere grant of citizenship to renounce entirely its jurisdiction over the individual members of this dependent race. There is not in this case in terms a subjection of the individual Indian to the laws, both civil and criminal, of the State; no grant to him of the benefit of those laws; no denial of the personal jurisdiction of the United States. 107

Mr. Justice Stewart's reliance on the Celestine case was tangential, 108 and for good reason; for if the case is to be taken as support for either the dissenters' position or that of the concurring opinion, it is the latter that must be deemed supported by it. At the very least it proves that the Criminal Appeals Act has been read loosely rather than strictly, whatever the Court's protestations to the contrary.

A stronger case for the Brennan position is to be found in the language of 105 Id. at 283.

106 See, e.g., Dahnke-Walker Milling Co. v. Bondurant, 257 U.S. 282 (1921); Ex parte Bransford, 310 U.S. 354 (1940); Case v. Bowles, 327 U.S. 92 (1946); Fleming v. Rhodes, 331 U.S. 100 (1947).

107215 U.S. at $290-91$. 108 See 361 U.S. at 458 n.8. 
the Court in United States $v$. Thompson. 109 In that case the defendant had successfully moved for dismissal of the indictment on the ground that a second presentation of a case to a grand jury which had initially refused to indict was invalid without the permission of the court. On the issue whether the motion was a special plea in bar, the Court, again in unanimity, spoke through Mr. Chief Justice White:

Testing, then, the existence of jurisdiction by the substantial operation of the judgment, and assuming for the purpose of that test that the United States possessed the right to submit the indictment to the second grand jury without leave of court, which right was denied by the judgment below, we are of opinion that the power to review the judgment is conferred by the provision of the statute quoted, (a) because its necessary effect was to bar the absolute right of the United States to prosecute by subjecting the exercise of that right, not only as to this indictment but as to all subsequent ones for the same offenses, to a limitation resulting from the exercise of the judicial power upon which the judgment was based; and (b) because a like consequence resulted as to the authority of the district attorney and the powers of the grand jury, since the exercise in both cases of lawful authority was barred by the application of unauthorized judicial discretion. ${ }^{110}$

The holding, on the question whether the motion qualified as a basis for appeal though the possibility of further prosecution was not necessarily precluded since judicial consent might be forthcoming, seems to have been destroyed by the Storrs case. 111 But the interesting point is that the question whether further prosecution was barred seemed to be the only test utilized by the Court; it paid no respect whatever to the possibility that "pleas in bar" was a closed category defined by legal history. Once again, however, it should be noted that, the Storrs issue to one side, this case would also qualify under the dissent's rationale of confession and avoidance, as well as the Brennan test. But the language could support only the latter.

The next relevant case112 might also have been utilized for the Brennan view. In United States $v$. Resler, 113 the only real issues involved problems of construction of the statute on which the information was based. The defendant had been charged with failure to secure a certificate from the ICC for the operation of certain motor vehicles in interstate commerce. The defense as-

109251 U.S. 407 (1920).

$110 \mathrm{Id}$. at $412-13$.

111 See text accompanying notes 120-23 infra.

112 In United States v. Chambers, 291 U.S. 217 (1934), jurisdiction was invoked by the United States both on the ground of constitutional question and plea in bar. See Statement as to Jurisdiction, pp. 4-5. Inasmuch as the defendant had pleaded guilty and the motion was in arrest of judgment, it would seem that the defendant had been put in jeopardy and the plea-in-bar category offered no avenue to the Court. The Court said nothing about the jurisdictional question, but jurisdiction seemed to rest plainly enough on the constitutional issue.

113313 U.S. 57 (1941). 
serted was that he had secured the operating rights by transfer from a certificate owner and that the statute did not require the approval of the ICC where the transfer involved less than twenty vehicles. The regulation promulgated pursuant to the statute required such permission; the issues in the case thus turned on the construction of the statute, including the questions whether the statute authorized the regulation. Jurisdiction properly rested on he ground of statutory construction, but that was not the basis proferred by the Government: "The decision prevents any further prosecution of the defendant upon counts one (1) to twelve (12), inclusive, and, therefore, is a decision sustaining a special plea in bar when the defendant has not been put in jeopardy." 114 Again we have the Brennan rationale, but the Court said not a word on the jurisdictional question. Whether the Court accepted jurisdiction on the thesis offered or on the patent alternative can only be the subject of speculation.

United States v. Monia115 involved the defense of immunity allegedly acquired by testifying before the grand jury, under subpoena from the United States, about the facts which gave rise to the indictment. Neither the Court nor the defendants raised any question about the propriety of the Court's jurisdiction under the plea-in-bar section. That the plea was in the nature of confession and avoidance, thus qualifying under both theories, is clear.

It was in the very next term that the Court decided the Hark case, 116 on which Mr. Justice Brennan placed such great reliance. The question raised by the defendant's plea was whether prosecution for violation of price control regulation could be maintained after the regulation had been withdrawn. The Court's language is ambiguous:

This appeal is authorized by the Criminal Appeals Act. That Act permits a direct appeal to this court, inter alia, from a judgment of a district court "sustaining a special plea in bar." The material question is not how the defendant's pleading is styled but the effect of the ruling sought to be reviewed; and we have, therefore, treated a motion to quash, the grant of which would bar prosecution for the offense charged, as a plea in bar within the purview of the statute. The defense here was in bar of the prosecution; to sustain it was to end the cause and exculpate the defendant.117

This could be read as saying nothing more than that the name affixed to the motion is not controlling; in this case the plea in confession and avoidance would bar further prosecution and therefore qualified under the statute. And, indeed, it was on this thesis that the Government invoked the jurisdiction of the Court: "Here the judgment was not based on the insufficiency of the indictment nor on irregularities in the grand jury proceedings. Rather it sus-

114 Statement as to Jurisdiction, p. 4.

115317 U.S. 424 (1943).

116 United States v. Hark, 320 U.S. 531 (1944).

$117 \mathrm{Id}$. at $535-36$. 
tained a defense, in the form of confession and avoidance, directed to the merits of the charges in the indictment. In substance, therefore, it was a judgment sustaining a special plea in bar."118

The last case in the category also involved a plea in the nature of confession and avoidance. In United States v. Provoo119 the Court affirmed, by per curiam order without opinion, the dismissal by a trial court of a treason indictment on the ground of the defendant's motion that the trial had been unreasonably delayed. While there are overtones of constitutional issues, it is clear that the Court's jurisdiction rested on the plea-in-bar provision.

4. Cases denying jurisdiction under the plea-in-bar provision. Three times the Court has specifically rejected the contention that the order appealed from was one granting defendant's plea in bar. The first of these was the Storrs case, 120 the prime reliance of the dissenters. In Storrs the defendant had succeeded on his plea in abatement that the indictment was defective because of the presence of improper personnel in the grand jury room. By the time the plea was sustained, the statute of limitations had run against the charge. The Government sought to demonstrate, largely on the basis of Thompson, ${ }^{121}$ that since the defendant was exculpated as a result of the trial court's action and inaction, the judgment was appealable as one granting a plea in bar. Mr. Justice Holmes rejected the argument:

The plea looks only to abating the indictment not to barring the action. It has no greater effect in any circumstances. If another indictment cannot be brought, that is not because of the judgment on the plea, but is an independent result of a fact having no relation to the plea and working equally whether there was a previous indictment or not. The statute uses technical words, "a special plea in bar," and we see no reason for not taking them in their technical sense. This plea is not a plea in bar and the statute does not cover the case.122

The Thompson case was distinguished in such fashion as to indicate that its vitality had been sapped. ${ }^{123}$

118 Statement as to Jurisdiction, pp. 5-6, United States v. Hark, 320 U.S. 531 (1944). (Emphasis added.)

119350 U.S. 857 (1955).

120 United States v. Storrs, 272 U.S. 652 (1926).

121 See text accompanying notes 109-111 supra.

122272 U.S. at 654.

123 Notice of the demise of Thompson may be premature in light of the Court's action in United States v. Durkee Famous Foods, 306 U.S. 68 (1939). There the defendants were indicted under the Elkins Act and succeeded in having the indictment quashed. A new indictment was filed pursuant to a statute which authorized the filing of a new indictment at the next term after the dismissal of the first if no appeal from the dismissal of the first was authorized. In Durkee, however, the second indictment was filed during the same term that the previous indictment had been dismissed. The defendants moved to dismiss the second indictment by a "plea in bar," because 1) the period of limitations had expired, 2) the Government had failed to comply with the strict terms of the statute by filing the 
If the language gives aid and comfort to the dissenters, as in Hark the holding is not necessarily inconsistent with the Brennan position; for the motion in Mersky had none of the defects for purposes of jurisdiction under this provision that made the judgment in Storrs unappealable.

The same unhappy result is to be deduced from the Murdock case, 124 which was the second pillar of the Brennan opinion. There the defendant was indicted for refusing to testify before a grand jury. His "plea in bar" asserted that the questions asked of him would have compelled him to give evidence tending to incriminate him and, therefore, he was protected by the fifth amendment. The plea was sustained and the indictment dismissed. The Court, speaking through $\mathrm{Mr}$. Justice Butler, then set out the language so dear to Mr. Justice Brennan:

The judgment necessarily determined that to require defendant to supply the information called for would be to compel him to incriminate himself and that therefore he did not unlawfully or wilfully refuse to answer. Its effect, unless reversed, is to bar further prosecution for the offense charged. It follows unquestionably that, without regard to the particular designation or form of the plea or its propriety, this court has jurisdiction under the Criminal Appeals Act.125

What neither Mr. Justice Brennan nor the dissenters pointed out was that the holding of the case was that the plea was not proper as a special plea in bar: "The matters set forth in the plea were mere matters of defense determinable under the general issue. ... A special plea in bar is appropriate where defendant claims former acquittal, former conviction or pardon ... but there is no warrant for its use to single out for determination in advance of trial matters of defense either on questions of law or fact."126 In short, the Court decided here, as it had in the first two statute of limitations cases above,127 that the Criminal Appeals Act created jurisdiction in the Supreme Court to determine whether the plea entered in the trial court could properly be considered a

second indictment at the same term instead of awaiting the later term, and 3) the dismissal of the first indictment was appealable under the Criminal Appeals Act. The trial court granted the motion, too late for the Government to comply with the specific terms of the statute.

The Supreme Court held the Government to the strict terms of the statute without saying a word about the jurisdictional problem which had vexed the Solicitor General. In so doing, the Court would seem to have followed Thompson rather than Storrs. The Government had pointed out that "the ruling of the [district] court is not of such nature as forever to bar prosecution of the offense, but, instead, recognizes the right of the Government to prosecute further at the term of court next succeeding the term at which the Court found the prior indictment defective." It referred the Court to both the Thompson and Storrs decisions. Statement as to Jurisdiction, p. 6. Rather than face the difficulties presented by the inconsistency in theory between Storrs and Thompson, the Court ignored them both.

124 United States v. Murdock, 284 U.S. 141 (1931).

$125 \mathrm{Id}$. at 147.

$126 I d$. at $150-51$.

${ }^{127}$ See text accompanying notes 91-93 supra. 
plea in bar; that it had jurisdiction to determine its own jurisdiction. In all three of these cases it decided that the plea was improper, and that it had no jurisdiction to entertain the appeal on the merits, but only to undo the order of the trial court which, in each instance, was rendered under the mistaken impression that the court was acting on a plea in bar. The result in Murdock may thus be read as inconsistent both with the Brennan and the FrankfurterStewart rationales.

The last of the cases to be treated here is United States v. Halsey, Stuart \& Co., 128 equally ambiguous as an answer to the Mersky problem. The indictment was for fraudulent use of the mails. After the Government produced a bill of particulars, the defendants successfully moved for dismissal on the indictment, an affidavit, and the bill taken together. The Government first asserted that jurisdiction in the Supreme Court rested on construction of the statute under which the indictment had been drawn. ${ }^{129}$ After the motion to dismiss had pointed out that the trial court indicated no ground for its action and, indeed, it had filed a certificate that no mention of the statute's construction had been made in its oral opinion, 130 the Government tried to rehabilitate its position by asserting that jurisdiction rested either on statutory construction or a plea in bar. With regard to the latter, the Government first offered the Brennan thesis:

The judgment of the District Court on the motion to quash necessarily determined that the facts charged in the indictment could not be proven by the Government. Unless reversed, its effect, under the doctrine of res adjudica, is to bar further prosecution for the offense charged. It follows that, without regard to the particular designation or form of the pleading or its propriety, this Court has jurisdiction under the Criminal Appeals Act. That clause of the Criminal Appeals Act giving an appeal to the United States [from judgments sustaining pleas in bar] is not limited like the earlier clauses to judgments based on the invalidity or construction of the statute upon which the indictment is founded. ${ }^{131}$

Apparently unwilling to rely solely on the persuasiveness of this argument, the Government offered an alternative not unlike the Frankfurter-Stewart position:

Applying these principles of law to the pleading in question, it seems clear that it was in substance a plea in bar. It gave as reasons why the defendants ought not to answer or to be placed on trial, matter contained in the bill of particulars and the affidavit annexed to the motion to quash. By the very wording of the motion the court was asked to quash the indictment because of matter outside the record. In plain words, the defendants by their motion to quash said they ought not to be prosecuted under the indictment because the bill of particulars and an ex parte

128296 U.S. 451 (1935).

129 Statement as to Jurisdiction, pp. 3-4.

130 Motion to Dismiss, p. 2.

131 Brief for the United States, pp. 18-19. 
affidavit showed that the Government could not prove its case against them. The motion to quash the indictment on the ground that the indictment, the affidavit and the bill of particulars taken together showed that no offense had been committed and the Government would be unable to make a case, was a plea directed to the merits of the case, and it therefore constituted a special plea in bar.132

Neither of the arguments appealed to the Court in light of the facts of the Halsey, Stuart case. It held that the record failed to reveal that the dismissal was not based on defects in the indictment, from which direct appeal to the Supreme Court did not, and does not, lie. Since this possibility existed, the Court would not exercise jurisdiction.

5. Conclusion. These cases, which constitute all those relevant to the question of the meaning of the plea in bar under the Criminal Appeals Act, prove three points clearly. First, Mr. Justice Brennan was wrong when he suggested that there was an established body of law which the Frankfurter-Stewart rationale would destroy. Second, Justices Frankfurter and Stewart were wrong in their proposition that the words "special plea in bar" had been given a technical meaning under the statute to which the Court had adhered with minor exceptions. Third, all members of the Court were wrong in believing that the Criminal Appeals Act had been strictly construed. It is possible to bring the holdings of all the cases, except some of the statute-of-limitations cases, within the Frankfurter-Stewart position. It is equally true that almost all of the cases, treating their actions rather than their language, fit the Brennan rationale.

In the absence of guidance from the prior authorities, the problem reduces itself to that which presented the conflict to the Court on the first jurisdictional ground.133 The same external factors would seem to call for choice of that construction which would limit the obligation of Supreme Court review most stringently.

\section{The Function and Utility of the Criminal APPEALS ACT JURISDICTION}

Some thirty-odd years ago Professor Frankfurter prophesied the retention of the Criminal Appeals Act jurisdiction and argued in its favor:

The history of latter-day judiciary acts is largely the story of restricting the right of appeal to the Supreme Court. The Criminal Appeals Act is a striking exception to this trend. It enlarged the domain of the Court's business and as a matter of bookkeeping brought to the Court each term on the average of ten additional cases. But the steady pressure, particularly since the Great War, to relieve the Supreme Court of business and to make the circuit courts of appeals to a large extent final appellate tribunals, has left this class of cases untouched. No serious proposal for cutting down the Supreme Court's business has attempted the elimination of this jurisdic-

132 Id. at 20.

133 See text accompanying notes 51-53 supra. 
tion. On the contrary, the latest enactment ... has expressly saved writs of error direct from the district courts under the Criminal Appeals Act, and naturally so. The reasons which impelled the enactment of the Act of 1907 remain. They will continue to be controlling. Congress is not apt to give the power of invalidating its legislation wholly to the inferior courts without an appeal as of right to the Supreme Court, and Congress is still less likely to do so with regard to criminal legislation. The criminal law is increasingly resorted to, for the "achievement of some social betterment rather than the punishment of the crimes as in the cases of mala in se." The defeat of these purposes is not likely to be entrusted to any tribunal other than the Supreme Court.134

The life of the law being what it is, however, answers which seemed pellucid in 1927 may not appear so clear in 1961. History has justified the prediction to this date; the question remains whether inertia or reason underlies the continuance of this burden on the Supreme Court's business.

Any evaluation of the Criminal Appeals Act jurisdiction should recognize at least three, and possibly five, distinct categories of cases that the Court is now required to hear. It is possible that some of the jurisdiction is properly vested. Thus, constitutional questions must be distinguished from statutory construction and both from motions in bar. Judgments rendered by the trial court before trial should also be distinguished from orders in arrest of judgment. In addition, care should be taken to separate those reasons which sustain a right of direct review in the Supreme Court from those which simply sustain the desirability of an appeal from the trial court. It is proposed, then, to examine the legislative history of the act with these distinctions in mind in order to ascertain the purposes of the act and then to weigh the experience under the act in recent years.

A. The Legislative History of the Criminal Appeals Act. An examination of the history of the legislation that culminated in the Criminal Appeals Act reveals a congeries of objectives and purposes, at least some of which are inconsistent. To an even greater extent than usual, the debates demonstrate an ignorance on the part of the legislators who enacted the law of the problems and issues which the act was intended to resolve. To make use of this material as a guide to the construction of the statute requires indulgence in the grossest of fictions. ${ }^{135}$ But the Court has consistently played the game.

1. The reports of the United States Attorneys General. Beginning in 1892,

134 Frankfurter \& LaNdis, The Business of the Supreme Court 119-20 (1928).

135 Cf. Jackson, J., concurring, in United States v. Public Utilities Comm'n, 345 U.S. 295, 319 (1953): "I should concur in this result more readily if the Court could reach it by analysis of the statute instead of by psychoanalysis of Congress. When we decide from legislative history, including statements of witnesses at hearings, what Congress probably had in mind, we must put ourselves in the place of a majority of Congressmen and act according to the impression we think this history should have made on them. Never having been a Congressmen, I am handicapped in that weird endeavor. That process seems to me not interpretation of a statute but creation of a statute." See also his opinion in Schwegmann Bros. v. Calvert Distillers Corp., 341 U.S. 384, 395 (1951). 
and for many years thereafter, the Attorneys General of the United States proposed legislation authorizing appeals by the Government in criminal cases. Attorney General Miller in his 1892 report ${ }^{136}$ pointed out that the defendant had a right of review in certain cases by writ of error to the Supreme Court and in "all other cases" to the circuit courts of appeals. "On the other hand, in no case is such writ of error allowed to the Government. This is contrary to the established practice in England and in most of the States of the Union." $137 \mathrm{He}$ urged the passage of a statute "authorizing a writ of error on behalf of the Government, in any case where a final judgment is rendered adverse to the Government, upon the sufficiency of an indictment, or upon any question preceding the prisoner's jeopardy."138 He thought Congress should pass such legislation unless it were "willing that its legislation shall be annulled by the decision of a single judge ...."139 Nothing was said about the necessity for direct review by the Supreme Court.

The following year Attorney General Olney endorsed this recommendation of his predecessor. ${ }^{140} \mathrm{He}$ repeated the recommendation in 1894.141 And Attorney General Griggs made a similar proposal in 1899: "The attention of Congress has heretofore been called by Attorneys-General to the importance of providing by legislation for an appeal on behalf of the United States from a judgment of the trial court in favor of the defendant upon demurrer to an indictment in a criminal proceeding under United States laws." 142 In the following year, his report suggested the necessity for such review in terms of the importance of the construction of the Constitution and federal statutes: "It is not conceived that such a law as is proposed would interfere in any way with the constitutional rights of defendants, but would permit the construction of statutes and of the Constitution in criminal cases, where such construction is adverse to the Government, to be submitted in regular course to the appellate courts, and to receive the construction of those courts, a course which is quite as reasonable and necessary in criminal cases as in cases involving mere property rights." 143

In 1903 Attorney General Knox, who later, as Senator Knox, played an important role in the passage of the Criminal Appeals Act, made the appeal: "When objection to the indictment is based upon some constitutional or other fundamental ground, a decision of this kind on demurrer, by a lower court, as it establishes a precedent, practically results in the abrogation of the statute upon which the indictment is based.... I urged, therefore, upon Congress the necessity of ... [entitling] the Government, when a demurrer to an indictment is sustained, to a review, upon writ of error, of the question of law in-

1361892 ATr'y GeN. ANN. REP. xxiv-Xxv.

137 Id. at xxiv.

138 lbid.

139 Id. at Xxv.
1401893 Att'y Gen. AnN. ReP. Xxvi. 1411894 ATt'y GEN. ANN. ReP. xxix. 1421899 ATT'Y GEN. ANN. REP. 33. 1431900 ATt'y GeN. ANN. REP. 40. 
volved therein, by the Supreme Court of the United States or by the circuit court of appeals." 144 Attorney General Moody renewed the recommendation in 1905145 and, in 1906, with legislation pending in Congress, brought forth additional arguments: "The indictment against the beef packers, returned by the grand jury after many months of deliberation was the result of investigations which had been made throughout the country by the Department of Justice, was rendered practically useless by the ruling of the judge, not relating to the merits of the case, the correctness of which the Department would have been very glad to have placed under the review of the appellate court."146 $\mathrm{He}$ reported that trial court judges and even United States commissioners had invalidated portions of a statute making it illegal for carriers to discriminate against employees on the ground that they were members of a labor organization. "It is monstrous that a law which has received the assent of the Senate, the House of Representatives, and the President can be nullified by the opinion of a single man, not subject to review by the court of appeals and the Supreme Court."147 He suggested, too, that authorization of such appeals would result in better administration of the criminal law for another reason: "It is the frequent if not the usual practice of judges sitting at nisi prius to rule doubtful questions of law in favor of the Government, for the very reason that the defendant has the right of appeal tho the Government has not, altho there would be no necessity for this commendable practise if each party had the right of appeal." 148 There is a slightly hollow sound to this concern for defendants.

The Criminal Appeals Act did not satisfy the Department of Justice. Immediately after its passage, Attorney General Bonaparte filed his complaint in his annual report. He pointed out that the Supreme Court had recognized that a right of appeal might be given to the Government in any case in which the defendant had not been put in jeopardy. $149 \mathrm{He}$, therefore, suggested two reforms: "I respectfully but earnestly urge that the terms of the act in question be made as broad as the decision of the Supreme Court permits.... I suggest that provision be made for raising compulsorily all questions of law which can be appropriately raised before that moment [of jeopardy] comes." 150 The following year the Attorney General asserted the necessity for Supreme Court jurisdiction over courts of appeals in criminal cases in which defendants had successfully appealed from judgments of conviction: "Under the existing

1441903 ATt'y GEN. ANN. ReP. vi.

1451905 Att'y GeN. ANN. Rep. 10.

147 Ibid.

1461906 ATT'y Gen. ANN. ReP. 4.

148 Ibid.

149 He was referring to United States v. MacDonald, 207 U.S. 120 (1907), which sustained the constitutionality of the Criminal Appeals Act.

1501907 ATT'y Gen. ANN. Rep. 5. The latter provision had been suggested and rejected by the Senate in the course of its debates over the Criminal Appeals Act. 
law, when a demurrer is sustained because of the invalidity or construction of the statute upon which the indictment is founded, the case may be taken direct to the Supreme Court of the United States. But, should the demurrer be overruled, a conviction had, and the case reversed and remanded by the Circuit Court of Appeals, on the ground that the demurrer should have been sustained by the trial court, such case can not be taken to the Supreme Court. This inconvenience should be remedied by an amendment of the act."151 The motivation was clearly set out; the right of review was sought primarily in anti-trust cases where "the wealth of the defendant usually renders an appeal on his or its part from any adverse judgment a matter of course. . .."152

Insofar as the demands of the Department of Justice reveal a basis for judgment on the desirability of Government appeals in criminal cases, they demonstrate only the desirability of review of trial court action. Neither in the demands of the Attorneys General nor in the arguments asserted by them is there a suggestion that the right of review should lie in the Supreme Court directly rather than in the courts of appeals with ultimate review in the high court when necessary.

2. President Theodore Roosevelt's Annual Message. A more direct connection may be shown between the President's annual message to Congress in 1906 and the Criminal Appeals Act than between the reports of the Attorneys General and that statute. Nothing seemed to enrage President Theodore Roosevelt more than to have his programs thwarted by the processes of the law. His anger at Mr. Justice Holmes's dissent in the Northern Securities Case is well known,153 Equally annoying to him was the failure of the Beef Trust case, 154 in which a verdict had been directed by Judge Humphrey in favor of the individual defendants. Roosevelt's response was logically unrelated to that decision, for none of the suggested rights of appeal would have been able to "cure" the result of Judge Humphrey's decision; the defendants had

1511908 Att'y Gen. ANn. ReP. 4.

152 Id. at 5.

$153 \mathrm{Mr}$. Justice Holmes wrote to Pollock in 1921: "A good letter from you, just after reading Theodore Roosevelt \& His Time, a class of work that I eschew. Of course I pretty well made up my package about him a good while ago, and I don't think I was too much disturbed by what you admit to and what was formulated by a Senator in his day, thus: 'What the boys like about Roosevelt is that he doesn't care a damn for the law.' It broke up our incipient friendship, however, as he looked on my dissent to the Northern Securities case as a political departure (or, I suspect, more truly, couldn't forgive anyone who stood in his way.) We talked freely later but it never was the same after that, and if he had not been restrained by his friends, I am told that he would have made a fool of himself and would have excluded me from the White House-and as in his case about the law, so in mine about that, I never cared a damn whether I went there or not. He was very likeable, a big figure, a rather ordinary intellect, with extraordinary gifts, a shrewd and I think pretty unscrupulous politician. He played all his cards-if not more. R.i.p." 2 HoLMES-POLLOCK LETTERS 63-64 (Howe ed. 1942).

154 United States v. Armour \& Co., 142 Fed. 808 (N.D. Ill. 1906). 
been put in jeopardy. ${ }^{155}$ None the less, spurred by that judgment Roosevelt called on Congress for the enactment of authorization for review of criminal cases at the behest of the Government:

It seems an absurdity to permit a single district judge, against what may be the judgment of the immense majority of his colleagues on the bench, to declare a law solemnly enacted by Congress to be "unconstitutional," and then to deny the Government the right to have the Supreme Court definitely decide the question. ${ }^{156}$

It was here that the demand for review of constitutional questions by the Supreme Court was made. But this was not all that T.R. wanted:

The importance of enacting into law the particular bill in question is further increased by the fact that the Government has now definitely begun a policy of resorting to the criminal law in those trust and interstate commerce cases where such a course offers a reasonable chance of success. 157

Again, the bill to which he was referring did not call for direct review in all cases in the Supreme Court. Thus, this aspect, too, of the origins of the Criminal Appeals Act demonstrates a demand for review, but only with regard to constitutional issues does that demand extend to Supreme Court review.

3. The congressional debates. The House of Representatives was obedient to the presidential command. A bill was introduced in the House that gave the United States the same rights of review in criminal cases as were available

155 There was a conflict among the sponsors of the Criminal Appeals Act in the Senate over this point. Senator Patterson asserted: "A special plea in bar, Mr. President, is a plea that does not relate to the guilt or innocence of the defendant in the sense as to whether he did or did not commit the act for which he was indicted. A special plea in bar is that which is set up as a special defense notwithstanding the defendant may be guilty of the offenses with which he is charged; it is for some outside matter; yet it may have been connected with the case. The special plea in bar that was filed by the indicted Chicago packers is a very good illustration of that. Their plea in bar set forth the fact of their having been induced or led, whatever it may have been, to make communications to the law officers of the Government with reference to their business that gave the district attorney evidence which enabled him to bring about the indictments and to help in their prosecution. That had no reference to the guilt or innocence of the accused. It was a pleading of a fact that was independent of the crime for which those packers had been indicted.

"Therefore, Mr. President, there could be no jeopardy in a case of that kind where there was decision upon the special plea in bar, because it is not under a plea of guilty or not guilty that the insufficiency of a special plea in bar is determined; it is non obstante whether the defendant is guilty or not guilty." 41 CoNG. REC. 2753 (1907).

On the other hand, Senator Nelson stated: "To my mind the decision of Judge Humphreys in Chicago regarding the meat inspection law cuts no figure at all. I desire to call the attention of Senators to the fact that under the amendment that the Judiciary Committee have tendered to the Senate an appeal could not have been taken in that case. In that case a jury was impaneled, and the question whether the defendants were entitled to immunity under the immunity law because they had furnished Mr. Garfield and the officials of his Bureau information was submitted to the jury, and the jury under instructions of the court found for the defendants. In that case the defendants under the Constitution had been in jeopardy and in that beef-trust case no appeal could lie." Id. at 2757. It is submitted that Nelson was the better lawyer on this issue.

15641 CONG. ReC. 22 (1906).

157 Ibid. 
to the defendant, except that a verdict for the defendant could not be set aside even if the appellate court ruled that the trial court had committed error.158 The report of the House Judiciary Committee again relied primarily on the necessity for appellate review in constitutional cases in support of the bill:

It is becoming more apparent every year that some statute should be enacted giving the United States the right to have decisions by courts upon points of law reviewed by the Supreme Court of the United States. ...

If this legislation is enacted it will be impossible for any court to declare any statute invalid without having their decision reviewed by a higher court. Under the present procedure a decision by the court in one part of the United States against the validity of a statute is followed in other districts, and has the effect largely of a precedent. The proposed bill would render the decisions more harmonious, as, after a ruling has been obtained from the Supreme Court, that ruling, of course, would be binding upon the subordinate courts of the United States.

We see no constitutional objection to this legislation, ${ }^{159}$ as the rights of the defendants are not in any wise prejudiced. Any verdict in his favor could not be set aside, and the constitutional provision as to defendant being twice placed in jeopardy would not be violated. 160

The bill passed the House without debate.161

The Senate was somewhat more recalcitrant. Then as now it proved less amenable than the House to the demands of the Chief Executive. The Senate Judiciary Committee offered a more complicated bill by way of substitute.162 It was a refined version of this bill that ultimately emerged as the Criminal Appeals Act. The bill did not provide for exclusive jurisdiction in the Supreme Court, nor did it limit review of decisions upsetting indictments to those based on statutory construction or constitutional validity.

The bill first came to the Senate floor on June 19, 1906, and was challenged by Senator Clay. The explanation offered by Senator Nelson for the need for such legislation was once more in terms of constitutional issues: "[S]ometimes an indictment is set aside on the ground that the law under which the indict-

15840 CoNG. Rec. 5408 (1906).

159 Congressional innocence of the case or controversy requirement in the federal courts is demonstrated over and over again in this legislative history. See 41 CoNG. REC. 2744-52, for an example of the discussion of the subject in the Senate. And see note 178 infra.

${ }^{160}$ H.R. Rep. No. 2119, 59th Cong., 1st Sess, 1, 3 (1906).

16140 CoNG. REC. 5408 (1906).

162 "That a writ of error may be taken by and on behalf of the United States from the district or circuit courts to the Supreme Court or the circuit courts of appeals, as prescribed in [the Circuit Courts of Appeals Act] ... in all criminal cases, in the following instances, to wit:

"From the decision or judgment quashing or setting aside an indictment;

"From the decision or judgment sustaining a demurrer to an indictment or any count thereof;

"From the decision arresting a judgment of conviction for insufficiency of the indictment;

"From the decision or judgment sustaining a special plea in bar, when the defendant has not been put in jeopardy. ..." S. REP. No. 3922, 59th Cong., 1st Sess. (1906). 
ment was found is held to be unconstitutional. The object is to allow the Government to take the case up and get a ruling of the Supreme Court."163 When Clay objected that the Government could simply reindict after dismissal of the indictment, Nelson suggested that an appeal under these circumstances might obviate the necessity for further proceedings in the event that the trial court was sustained. The bill was then put over for absence of unanimous consent to consider it at that time.

An amendment which had been offered on the 19th of June, providing that a verdict in favor of a defendant could not be set aside on appeal, was first approved and then rejected on the floor at the session of the $23 \mathrm{rd}$. At that time Senator Spooner asked whether the bill was limited "to questions which arise before the impaneling of the jury." 164 Nelson assured him that it was limited to cases "where the party has not been put in jeopardy."165 Senator Mallory wanted to know whether it applied "to a motion in arrest of judgment." 166 Despite the very specific language of the bill, its manager, Senator Nelson, assured Mallory that it did not apply "to a motion in arrest of judgment, only for insufficiency of indictment; not for any other ground."167 Senator Heyburn nevertheless objected to the provision relating to motions in arrest of judgment, apparently on the ground of double jeopardy. Again, debate was forestalled by withdrawal of unanimous consent to proceed.

Indeed, fuller debate on the bill did not take place until the second session of the Congress. The bill reported out of committee on January 29, 1907, had been amended to require that all objections to the form of the indictment had to be taken before the jury was impanelled. Debate on the bill contained many amendments and changes irrelevant to the statute which ultimately emerged. Nelson again relied on the problem of constitutional questions in support of the bill, 168 and invoked the support of the Harvard Law Review in justification of the measure. 169 Neither the argument nor the authority proved conclusive.

Senator Bacon, in support of the bill, assured his colleagues that the great principle prohibiting double jeopardy, a principle he endorsed, was not in any way affected by the bill. The argument over the meaning of double jeopardy took most of the debate time. Of interest to the construction of the statute as it ultimately evolved was Bacon's assertion that the provision relating to pleas in bar "was inserted in the bill out of an abundance of caution."170 The

16340 CONG. ReC. 8695 (1906).

164 Id. at 9933.

165 Ibid.

166 Ibid.

167 Ibid.

16841 CoNG. Rec. 2190 (1907). See also Senator Bacon's argument, id. at 2192, and Senator Patterson's statement, id. at 2753.

169 Id. at 2191.

170 Ibid. It was clear that some Senators at least regarded the assertion of the statute of limitations as a plea in bar, raising a proper question for review if jeopardy had not attached. See $i d$. at 2749-50. 
bill's supporters relied on United States $v$. Ball171 for the proposition that a defendant who succeeded on a motion in arrest of judgment could be tried again.

It was made clear by Senator Nelson that the constitutional issues were expected to be resolved by the Supreme Court.172 $\mathrm{He}$ also made it clear, however, that the target of the bill was not the constitutional decisions so much as the inhibitions that the courts were placing on the enforcement of "social legislation." In retort to the suggestion that we had managed for one hundred years without such right of appeal in the Government, Nelson said:

It is not until recent years that we found the necessity of passing the Sherman antitrust law. It was not until recent years that we found the necessity of passing a law to regulate interstate commerce and the transportation of interstate commerce. It is not until recent times that we found the necessity of passing a national pure-food law, providing for the inspection of the foods of the people. It is not until recently that we found the necessity of passing a national quarantine law.... We as the representatives of the people of the United States have found it necessary to enact this most important legislation to which I have called your attention, and the question now before us is whether we will allow a nisi prius judge of an inferior court to render ineffective our efforts in this behalf to protect the American people against trusts and monopolies and other dangerous things; whether we will allow ourselves to be handicapped and crippled by the decision of an inferior nisi prius judge. ${ }^{173}$

The attack here was on the nisi prius judge and there was no suggestion or demand that review be directly in the Supreme Court.

Senator Clarke sought to restrict the right of review by the Government in criminal cases to constitutional issues and questions of construction of the statute under which the charge was bought. His amendment was accepted174 and the bill thus agreed upon by the Senate was substantially the one that became the Criminal Appeals Act, with one important exception. ${ }^{175}$ The bill

171163 U.S. 662 (1896).

172 "To me it seems strange that a nisi prius judge in a distant part of the country shall take it upon himself to pronounce an enactment of Congress unconstitutional and void. There is no other country on the face of the earth that I know of where the courts of the country can veto legislation. In this country there is a double veto on our legislation. First, the President can veto a bill that we pass, and then after we have passed a law the courts can veto it. We can overcome the veto of the President, but under our system and our jurisprudence we can not overcome the veto of the courts.

"Where it relates to an important subject that is of national concern, in which the welfare of all the people of the United States is involved, before an act of Congress should be pronounced unconstitutional we should have the opinion of the highest court of the landthe Supreme Court. In my opinion no other court ought to have the ultimate power to place a veto upon an act of Congress." 41 CoNG. REc. 2757 (1907).

173 Ibid.

174 Id. at $2819-20$.

175 The bill as amended is set out id. at 2825 , 
approved by the Senate 176 was not restricted to direct review in the Supreme Court.

Back in the House, the Senate amendment met with devastating comment from the sponsors of the original bill. Jenkins insisted on the right to go to the Supreme Court in any case in which the judgment was adverse to the Government, even where the defendant had been found not guilty by the jury. $177 \mathrm{He}$ proposed to free the defendants in such event, but none the less to get a determination from the Supreme Court of what even the Senators had recognized as a moot question. In short, he reasserted the proposition that the Government had a right to an advisory opinion from the Supreme Court. $178 \mathrm{He}$ complained that under the Senate bill no right of review was provided for a case successfully appealed by the defendant to a court of appeals. 179 His main complaint was that no right of review was afforded in cases such as the "beef-trust" case.

The House referred the amendment bill to its Judiciary Committee 180 which rejected it. The Senate and House agreed to a conference.181 The legislative conference is as sancrosanct and mysterious as the judicial conference. Nothing is publicly known about what occurred in the conference. What emerged was the Senate bill modified in small details, except that it placed review exclusively in the Supreme Court, obviously a concession to the learned Mr. Jenkins. Both Houses agreed to the report ${ }^{182}$ and the Criminal Appeals Act became law when signed by the President.

The legislative history reveals that the utilization of Supreme Court jurisdiction was not even then a prime objective of the legislators except with regard to constitutional cases. With reference to non-constitutional cases the goal seems to have been to secure a right of review where the defendant had not been put in jeopardy and to have such review follow appropriate appellate channels with ultimate power in the Supreme Court. That the statute is not an accurate reflection of these motivating desires is not surprising in light of the legislative history. The statute, like many others, was a compromise among several divergent forces. The division in the Senate was primarily between those who wanted limited review and those who wanted none. The division between the House and Senate was between those who wanted complete review and those who wanted limited review. No adequate consideration was given to the choice of a reviewing court. No reason at all was given for the

176 Id. at 2834.

177 Id. at 3044-47.

178 Id. at 3046: “. . . it does not make any difference to me whether it is a moot case or not; the Department of Justice and the President of the United States have asked that the House bill become a law."

$179 \mathrm{Id}$. at 3045 . See note 151 supra.

181 Id. at $3647,3623$.

13041 CoNG. Rec. 3047 (1907).

182 Id. at $3994,4128$. 
inclusion of the pleas-in-bar section except that the driving force for review in criminal cases grew out of the "Beef-Trust" case.

B. Recent Experience under the Criminal Appeals Act. Time and space being relevant factors in the presentation of this paper, the analysis of the effect and utility of the jurisdiction given the Supreme Court under the Criminal Appeals Act will be confined to the cases decided during the last ten complete terms of the Court.

1. Quantitative aspects of the Criminal Appeals Act jurisdiction. The following table reveals, in quantitative terms, the role of the Criminal Appeals Act in the business of the Supreme Court:

TABLE I

Criminal appeats ACt Cases in the Supreme Court*

O.T. 1950-O.T. 1959

\begin{tabular}{|c|c|c|c|c|c|c|c|}
\hline \multirow{2}{*}{ Term } & \multirow{2}{*}{ NuMrerer } & \multicolumn{3}{|c|}{ Disposition } & \multirow{2}{*}{$\begin{array}{l}\text { CoNsTITU- } \\
\text { TIONAL. }\end{array}$} & \multirow{2}{*}{ StatUTORY } & \multirow{2}{*}{$\begin{array}{l}\text { MotroN } \\
\text { IN BAR }\end{array}$} \\
\hline & & Aff'd & Rev'd & Remand & & & \\
\hline $\begin{array}{l}1950 \ldots \ldots \\
1951 \ldots \ldots \\
1952 \ldots \ldots \\
1953 \ldots \ldots \\
1954 \ldots \ldots \\
1955 \ldots \ldots \\
1956 \ldots \ldots \\
1957 \ldots \ldots \\
1958 \ldots \ldots \\
1959 \ldots \ldots\end{array}$ & $\begin{array}{r}1 \\
5 \\
11 \\
4 \\
1 \\
2 \\
12 \\
3 \\
2 \\
2\end{array}$ & $\begin{array}{l}0 \\
3 \\
4 \\
2 \\
0 \\
1 \\
2 \\
0 \\
0 \\
1\end{array}$ & $\begin{array}{r}1 \\
2 \\
6 \\
2 \\
1 \\
1 \\
10 \\
3 \\
2 \\
1\end{array}$ & $\begin{array}{l}0 \\
0 \\
1 \\
0 \\
0 \\
0 \\
0 \\
0 \\
0 \\
0\end{array}$ & $\begin{array}{l}0 \\
1 \\
1 \\
1 \\
0 \\
0 \\
0 \\
1 \\
0 \\
0\end{array}$ & $\begin{array}{r}0 \\
2 \\
5 \\
3 \\
1 \\
1 \\
12 \\
2 \\
2 \\
2\end{array}$ & $\begin{array}{l}1 \\
2 \\
4 \\
0 \\
0 \\
1 \\
0 \\
0 \\
0 \\
0\end{array}$ \\
\hline Totals... & 43 & 13 & 29 & 1 & 4 & 30 & 8 \\
\hline
\end{tabular}

* The forty-three cases were handled in thirty-two dispositions. Eleven cases were disposed of by per curiam memoranda. There were thirty full opinions, not including the one ordering a remand.

Of the constitutional cases, all four resulted in reversals. Three motion-in-bar cases were aff rmed and five reversed. Of the statutory construction cases, ten were affrmed, twenty were reversed.

Table I shows that a very small part of the Court's business is there by reason of the Criminal Appeals Act. During the ten terms the Court disposed of approximately two hundred to two hundred and fifty cases per term on the merits, the Criminal Appeals Act contributing only about four and one half cases on the average. Of the approximately one hundred and twenty-five opinions per term, only an average of three could be charged to this head of jurisdiction. It is possible, therefore, to suggest that the Criminal Appeals Act business is de minimus and should be left alone. Two considerations would suggest an opposite conclusion. First, in any given term the number of Criminal Appeals Act cases could become substantial. Second, even if the average were maintained each term, if the Court is now operating at the maximum of its capacity every unwarranted case brought under the Criminal Appeals Act 
precludes the entertainment of a case under the Court's discretionary jurisdiction that might otherwise be heard.

If the quantitative test suggested by Professor Frankfurter is valid, the figures reveal a reason for the retention of the jurisdiction. In 1928 he asserted that: "The proportion of reversals to affirmances, substantially two to one, under this Act illustrates the importance of permitting review by the Government in this class of cases." 183 The ratio of reversals to affirmances remains about the same. If the cases were to be divided into three categories, it would appear that the statistical argument is strongest in favor of the retention of the jurisdiction based on the constitutional question and weakest with reference to the pleas-in-bar jurisdiction.

Whether the statistics reveal any further arguments pro or con must be left to those more adept at the "numbers game" that now plays so important a part in "behavioral sciences."

2. Some qualitative aspects of the Criminal Appeals Act jurisdiction. Any qualitative analysis of the importance of the cases brought to the Court under the Criminal Appeals Act necessarily involves subjective judgments that are not refinable to the neatness of statistical data. In each term now we get a demonstration of the vivid difference of opinion within the Court itself over the desirability of taking FELA cases. One can only say on that question, as on that of the Criminal Appeals Act, that one or the other of the opinions is the better one. But it is appropriate to note again this paper's bias against retention of compulsory jurisdiction in the Supreme Court in order that the reader may establish his "bias against bias."184

a. Constitutional-question cases. United States v. Spector 185 was brought to the Supreme Court under the Criminal Appeals Act after the trial court had dismissed the indictment on the ground that Section 20 of the Immigration Act 186 was void for vagueness. That section made it a criminal offense for an alien, ordered deported for advocating the overthrow of the government by force and violence, "wilfully [to] fail or refuse to make timely application in good faith for travel or other documents necessary to his departure." At first glance it would appear clear that the resolution of this question was of widespread importance during the 1950's with the Cold War at its height and Senator McCarthy at his zenith. The Court narrowly sustained the statute in an opinion by Mr. Justice Douglas. Mr. Justice Black dissented on the ground that the statute was too vague. Justices Jackson and Frankfurther also dissented. They found the law unconstitutional because its provisions did not afford the court which tried the defendant the opportunity to pass on the

183 FrankFurTer \& LANDIS, op. cit. supra note 134, at 120 n.76.

184 See Hand, Thomas W. Swan, 57 YALE L.J. 167, 172 (1947).

185343 U.S. 169 (1952).

18664 Stat. 1010 (1950), 8 U.S.C. § 1252(e) (1958). 
validity of the deportation order. Strangely enough, Mr. Justice Douglas said that the issue relied on by these dissenters was not open for consideration because it had not been timely raised. ${ }^{187}$ Even more strange, however, is the fact that despite the invitation of the Jackson opinion (when combined with the majority's refusal to consider the issue) to attack the statute again on constitutional grounds, the issue has not since been considered. ${ }^{188}$

The second of the four cases during this period in which the Court passed on a constitutional question raised under the Criminal Appeals Act was United States $v$. Kahriger. 189 The constitutionality of the federal gambling $\operatorname{tax} 190$ was there put in issue and there could be little question but that this case presented problems appropriate for Supreme Court disposition. There had been a division among the lower courts passing on the question.191 Many cases presenting the same questions were pending in the lower courts. ${ }^{192}$ The case presented substantial constitutional issues, as the dissents of Justices Black, Frankfurter, and Douglas revealed. The applicability and meaning of earlier Supreme Court decisions, especially United States v. Constantine,193 were clearly raised. Indeed, all the strong reasons for the enactment of the Criminal Appeals Act called for the exercise of jurisdiction by the Supreme Court in this case, with one possible exception. In light of the appeals from adverse judgments taken by defendants, it is apparent that the questions raised by this case would ultimately have been brought to the Supreme Court for disposition even in the absence of the warrant for appeal under the Criminal Appeals Act.

United States v. Harriss ${ }^{194}$ also justified the desirability of direct appeal in constitutional cases, but at the same time it pointed up a defect in the appellate jurisdiction provided. The question was the constitutionality of the Federal Regulation of Lobbying Act, 195 challenged for vagueness and for violation of the First Amendment. Although there was no demonstration as in Kahriger that a large number of cases were pending under the statute, it was evident that the statute affected the activities of many people. Again the substantiality of the questions presented was affirmed by the cogent arguments in the dissents of Justices Black, Douglas, and Jackson. It is supported also by the fact that in sustaining the statute, Mr. Chief Justice Warren, for the

187 Cf. Terminiello v. Chicago, 337 U.S. 1 (1949) (Douglas, J.).

188 See Heikkinen v. United States, 355 U.S. 273 (1958).

189345 U.S. 42 (1953).

190 INT. Rev. CODE OF $1954 \S 3285$.

191 See 345 U.S. at 25 n.2.

192 See briefs of amici curiae filed in the Supreme Court in this case.

193296 U.S. 287 (1935).

194347 U.S. 612 (1954).

19560 Stat. 812,839 (1946), 2 U.S.C. $\$ \S 261-70$ (1958). 
Court, gave it a much narrower reading than that sought by the Government 196 and thus, presumably, precluded some indictments which the Government might otherwise have sought.

The unfortunate aspect of the Court's jurisdiction pointed up by the case results not from the language of the act itself but rather from the gloss put on it by the Court. The Chief Justice, following clear precedent, ${ }^{197}$ ruled that the Court could not consider "the sufficiency of the information as a criminal pleading. Our review under the Criminal Appeals Act is limited to a decision on the alleged 'invalidity' of the statute on which the information is based. In making this decision, we judge the statute on its face." 198 This doctrine has the unfortunate consequence of confining the Court to consideration of what might well be a hypothetical case, ${ }^{199}$ since the construction of the indictment by the trial court might be an unwarranted one. Some of the undesirable results of confining the Court to the consideration of an unreal question are demonstrated by the confusion necessarily following the Court's decision in the Colgate case. ${ }^{200}$ This is not the place to expatiate on the evils of advisory opinions, but certainly there is no good reason why the Court should not be in a position to deal with the actual cases before it and consider the validity of the construction given the indictment by the trial court judge.

"The issue" in United States v. Sharpnack 201 was "whether the Assimilative Crimes Act of 1948, 18 U.S.C. $\S 13$, is constitutional insofar as it makes applicable to a federal enclave a subsequently enacted criminal law of the State in which the enclave is situated." The Court, over the dissents of Justices Black and Douglas, took the opportunity to bring its doctrine with reference to assimilative crime statutes into line with the great bulk of its decisions on the power to incorporate state law by reference, whether the state law was in existence at the time of the federal enactment or came into existence thereafter. If the case itself was not one of great importance to the community, the problem of the appropriate doctrine certainly warranted Supreme Court attention. As the Government pointed out in its brief:

The importance of the question in the administration of criminal law within federal enclaves is self-evident. As we become further removed from the date of the 1948 enactment, the number of new state enactments which will be affected by section 13 will increase. It is important that Congress know whether future legislation

196347 U.S. at 619-20.

197 United States v. Petrillo, 332 U.S. 1, 5 (1947); United States v. Borden Co., 308 U.S. 188, 193 (1939); see ROBERTSON \& KIRKHAM, JURISDICTION of the SUPREME COURT OF THE UnIted StaTes \& 185 (2d ed. Wolfson \& Kurland 1951).

198347 U.S. at 617.

199 Cf. United States v. UAW, 352 U.S. 567, 590-92 (1957).

200 See Levi, The Parke, Davis-Colgate Doctrine: The Ban on Resale Price Maintenance, 1960 SUP. CT. Rev. 258.

201355 U.S. 286 (1958). 
is necessary to keep abreast of changing state laws. Moreover, the implications of the decision may go beyond the subject matter of 18 U.S.C. 13, for in many fields Congress has seen fit to refer to provisions of state law for the purpose of federal legislation. ${ }^{202}$

b. Statutory-construction cases. The first group of cases to be considered under this heading might have been as properly placed in the earlier category. Generally they involve cases in which the constitutional issue has been avoided by construction of the statute underlying the indictment. And perhaps because of their affinity to the constitutional cases, they too demonstrate an importance, perhaps calling for Supreme Court adjudication, that is not common to most of the statutory construction cases.

United States v. Five Gambling Devices 203 brought three cases to the Court on the question whether registration was required of gambling devices that had not been transported in interstate commerce. One of the three cases was an action in rem against the devices themselves. It came to the Court not under the Criminal Appeals Act, but rather under Section 1252 of the Judicial Code authorizing appeals in civil cases directly from the trial court where it has held a statute unconstitutional. Both of the other cases arose under the Criminal Appeals Act. In one the district court had held that the statute did not authorize prosecution where the devices had not been utilized or transported in interstate commerce; in the other the statute was held invalid because it was applicable to such instrumentalities. The Court construed the statute as not applicable to transactions not in interstate commerce for the purpose of avoiding a constitutional question and, on that basis, affirmed the judgments of the trial courts. Justices Black and Douglas dissented on the ground that the statute was too ambiguous to permit criminal sanctions to follow from its alleged violation.

Similarly in United States $v$. Green ${ }^{204}$ the Court was faced with a problem of statutory construction with the possibility that one construction might mean that the statute was invalid. The question there was whether the Hobbs Act ${ }^{205}$ made it criminal to compel payment of wages for services not to be performed, even where the payment did not go to those exerting the power of compulsion. The Court rejected the trial court's construction and sustained the validity of the indictment over the dissent of the Chief Justice and Justices Black and Douglas, who believed that the Court lacked jurisdiction over the appeal. They thought that the trial court's action in vacating a judgment after conviction was based on issues other than constitutionality or statutory construction. Again in United States v. UAW 206 the problem of statutory construction involved the possibility of unconstitutionality. The trial court had

202 Jurisdictional Statement, p. 4.

203346 U.S. 441 (1953).

20518 U.S.C. $\S 1951$ (1958).

204350 U.S. 415 (1956).

206352 U.S. 567 (1957). 
ruled, in order to avoid the constitutional question, that the use of union dues to sponsor commercial television broadcasts did not violate Section 610 of the Criminal Code which prohibited an organization from making "a contribution to expenditures in connection with" an election to federal office. The majority reversed the trial court without reaching the constitutional question.

United States $v$. Witkovich ${ }^{207}$ also had a constitutional problem lurking in the background. There the question was whether Section 242(d) of the Naturalization Act of $1952^{208}$ authorized an indictment for wilful failure to give information to the Immigration and Naturalization Service where the information refused related to the defendant's affiliation with Communist organizations. The district court construed the statute not to include such refusal and the Supreme Court affirmed the trial court's action.

When the cases move away from the area where the construction might create or eliminate a constitutional question, it is difficult to find any feature distinguishing them from a host of other cases which are left for appellate resolution by the courts of appeals with a discretionary right of review in the Supreme Court. A mere recitation of the cases should suffice to make this apparent.

Three of the cases involved statutes seeking elimination of improper political practices. United States $v$. Bramblett ${ }^{209}$ presented the question whether a false representation to a disbursing office of the House of Representatives by a congressmen constituted a false representation to a "department or agency" within the meaning of the statute. The Court held that it was and reversed the trial court's order in arrest of judgment. In United States v. Hood,210 the Court decided that Section 215 of the Criminal Code was violated by the solicitation or receipt of money in payment for a promise of appointive office, even though the office in question was not in existence but merely contemplated at the time that the money changed hands. And in United States $v$. Shirey, ${ }^{211}$ an offer to contribute to a political party in exchange for the use of a congressman's influence to secure a postmastership was held to violate the statute because the Republican Party fell within the definition of the word "person" as it was used in the statute.

Then there were some tax cases. One may agree with Professor Lowndes' thesis that the Court should retain its appellate powers over criminal tax matters ${ }^{212}$ without believing that direct review of district courts by the Supreme Court is desirable. In United States v. Dixon ${ }^{213}$ the question that the Court

207353 U.S. 194 (1957).

20866 Stat. 163, 211 (1952), as amended, 8 U.S.C. § 1252(d) (1958).

209348 U.S. 503 (1955).

210343 U.S. 148 (1952).

211359 U.S. 255 (1959).

212 Lowndes, Federal Taxation and the Supreme Court, 1960 SuP. CT. Rev. 222.

213347 U.S. 381 (1954). 
had to answer was whether Section 3116 of the Internal Revenue Code created a criminal offense or was not intended to impose criminal penalties. The Court ruled that when Section 3116 was read with Section 3115, it was clear that criminal sanctions were warranted. Whether failure to file an unverified "information return" constituted failure to file a tax "return" within the meaning of the statute was the issue answered in United States v. Carroll.214 And in United States v. Beacon Brass, 215 the question was whether making false statements to Treasury employees constituted a violation of Section 145(b) of the Internal Revenue Code.

Various other statutory terms were defined by the Court under its Criminal Appeals Act jurisdiction. "Laws" includes "local court rules" for purposes of the perjury statute;216 it also includes regulations of the Florida Game and Fresh Water Fish Commission for purposes of the Federal Black Bass Act.217 The word "stolen" in the National Motor Vehicle Theft Act is not restricted to common-law larceny. ${ }^{218}$ A partnership is susceptible of a charge of violating ICC regulations;219 and a husband and wife can be guilty of conspiracy.220 The Court also decided what the proper unit for figuring violations of the Fair Labor Standards Act should be,221 that a punchboard sent through the mails did not constitute "gambling paraphernalia that may be used to set up a lottery or similar scheme," 222 and what the proper venue was for the trial of the charge of remaining in the United States after expiration of the necessary permit.223 To these may be added the weighty substantive question in the Mersky case, already the subject of overlong discussion.224

c. The motion-in-bar cases. All the motion-in-bar cases, not merely those of the last few years, have already been discussed 225 and need not be considered here.

3. Conclusion. It would seem that experience supports the original conception of calling on the Supreme Court to review directly criminal cases in which

214345 U.S. 457 (1953).

215344 U.S. 43 (1952).

216 United States v. Hvass, 355 U.S. 570 (1958).

217 United States v. Howard, 352 U.S. 212 (1957).

218 United States v. Turley, 352 U.S. 407 (1957).

219 United States v. A \& P Trucking Co., 358 U.S. 121 (1958).

220 United States v. Dege, 364 U.S. 51 (1960).

221 United States v. Universal Corp., 344 U.S. 218 (1952).

222 United States v. Halseth, 342 U.S. 277, 279 (1952).

223 United States v. Cores, 356 U.S. 405 (1958).

224 In addition to these, the Court disposed of several other cases arising under this provision of the Criminal Appeals Act by per curiam memorandum order: United States v. Wilson, 344 U.S. 923 (1953); United States v. American Freightways Co., 352 U.S. 1020 (1957); United States v. Hunt, 354 U.S. 932 (1957).

225 See text beginning at note 74 supra. 
the district court has held a statute unconstitutional and the defendant has not been put in jeopardy. At the same time it would appear equally desirable to permit the Court to review the entire case brought to it under such circumstances and not limit it to what might be a hypothetical issue of constitutionality.

Of the statutory-construction cases, those which also involve the possibility of constitutional defect come close to warranting direct Supreme Court intervention. On the other hand, so long as the statute is not in jeopardy by reason of its invalidation at the hands of a trial court, it would probably be as well to sift the cases through the courts of appeals in the same way that appeals from convictions and civil cases of the same nature are treated. The statutoryconstruction cases not involving even this shadow of constitutional issues clearly do not qualify for direct Supreme Court review. Nor does Professor Frankfurter's rationale226 seem to support these cases as proper for the imposition of compulsory jurisdiction. And it would seem even clearer that the kinds of cases brought to the Court because of the motion in bar are not worth of commanding the Supreme Court's time except when it might be necessary to resolve conflicts among the courts of appeals.

\section{A Recommendation FOR Revision of the Criminal Appeals ACT}

Certainly neither the legislative history nor the experience under the statute afford any reason why the bulk of the jurisdiction imposed on the Supreme Court by the Criminal Appeals Act ought to be continued. Revision is called for and should take the following form:

A. Criminal cases in which the defendant has not been put in jeopardy and in which a trial court has found a statute of the United States unconstitutional should be appealable directly to the Supreme Court. The primary business of the Court is the resolution of constitutional problems. This is recognized in the allocation of direct review in civil cases wherever a lower federal court holds a federal statute unconstitutional.227 There seems no good reason why the same right of review ought not to be afforded in criminal cases.228 But, if the Court is to retain this jurisdiction, it must be made clear that it is free to review the entire case, including the questions, if any, involving construction of the indictment or construction of the statute, so that constitutional issues

226 See text accompanying note 134 supra.

22728 U.S.C. $\$ 1252$ (1958). See ROBERTSON \& KIRKHAM, op. cit. supra, note 197, at $\S \S 113-18$.

${ }^{228} \mathrm{~A}$ similar argument could be made with regard to criminal cases that parallel civil actions under the Expediting Act. 56 Stat. 198 (1948), as amended, 15 U.S.C. \$ 28 (1958), 49 U.S.C. $\$ 44$ (1958). See RoBERTSON \& KIRKHAM, op. cit. supra note 197, at \$§169-74. The absence of any substantial reason for direct appeals under the Expediting Act, however, hardly provides a reason for such direct appeal in comparable criminal cases. 
may properly be avoided where possible. It is no boon to the effectuation of our judicial processes to place a hypothetical constitutional issue before the Court in the form of an appeal from a part of a lower court judgment.

B. In all other criminal cases in which the defendant has not been put in jeopardy, the Government should be given a right to appeal from an adverse final judgment 229 to the appropriate court of appeals. 230 The courts of appeals are now the primary, and ordinarily the ultimate, courts of review in criminal matters where the appeal is taken by the defendant. There is no suggestion that, subject to the usual certiorari jurisdiction, they cannot perform equally well where the appeal is by the United States as where it is by the defendant. The reasons for authorizing such review by courts of appeals are basically the reasons why Congress passed the Criminal Appeals Act in the first place. The legislative history, including the reports of the Attorneys General, suggests the need for such jurisdiction. It does not suggest any good reason why the jurisdiction should be vested directly in the Supreme Court.

In addition to satisfying all the demands for the right of Government appeals, the suggested simplification would remove from the Supreme Court docket the numerous and wearisome jurisdictional problems of the kind presented by the Mersky case. Certainly no evidence has been adduced demonstrating the desirability of drawing lines of jurisdiction in terms of "special pleas in bar."

If only as a first step toward the reduction of the Supreme Court's compulsory jurisdiction, an amendment reducing the Criminal Appeals Act jurisdiction to constitutional cases would seem a happy one. At worst it will put the discretion in the Supreme Court rather than the Solicitor General to determine which of the non-constitutional questions call for high court adjudication.

229 Cf. Carrol v. United States, 354 U.S. 394 (1957).

${ }^{230} C f$. United States v. Johnston, 227 F.2d 745 (3d Cir. 1955), aff'd, 351 U.S. 215 (1956). 